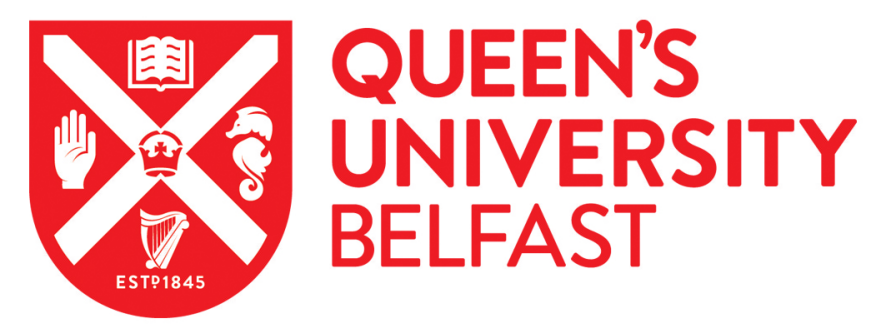

\title{
Contribution of genetic factors to platinum-based chemotherapy sensitivity and prognosis of non-small cell lung cancer
}

Pérez-Ramírez, C., Cañadas-Garre, M., Molina, M. Á., Robles, A. I., Faus-Dáder, M. J., \& Calleja-Hernández, M. Á. (2017). Contribution of genetic factors to platinum-based chemotherapy sensitivity and prognosis of non-small cell lung cancer. Mutation research/Reviews in Mutation Research, 771, 32-58.

https://doi.org/10.1016/j.mrrev.2016.11.003

Published in:

Mutation research/Reviews in Mutation Research

Document Version:

Peer reviewed version

Queen's University Belfast - Research Portal:

Link to publication record in Queen's University Belfast Research Portal

\section{Publisher rights}

Copyright 2017 Elsevier.

This manuscript is distributed under a Creative Commons Attribution-NonCommercial-NoDerivs License

(https://creativecommons.org/licenses/by-nc-nd/4.0/), which permits distribution and reproduction for non-commercial purposes, provided the author and source are cited.

\section{General rights}

Copyright for the publications made accessible via the Queen's University Belfast Research Portal is retained by the author(s) and / or other copyright owners and it is a condition of accessing these publications that users recognise and abide by the legal requirements associated with these rights.

Take down policy

The Research Portal is Queen's institutional repository that provides access to Queen's research output. Every effort has been made to ensure that content in the Research Portal does not infringe any person's rights, or applicable UK laws. If you discover content in the Research Portal that you believe breaches copyright or violates any law, please contact openaccess@qub.ac.uk. 


\section{INDEX}

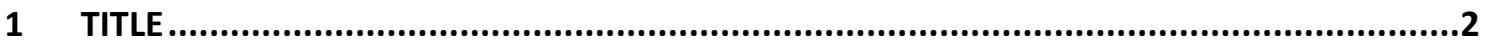

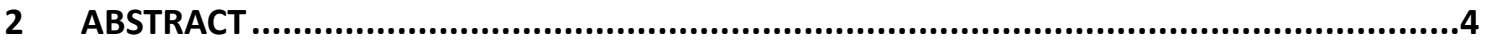

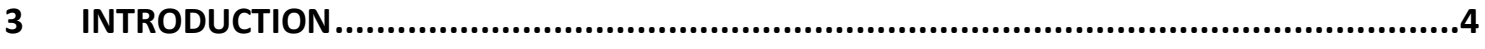

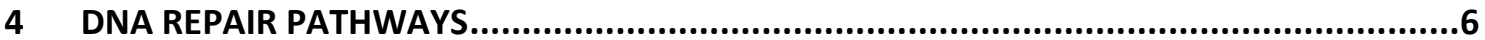

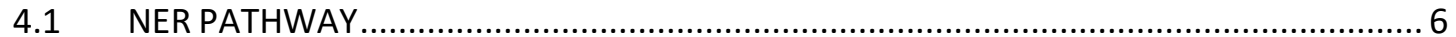

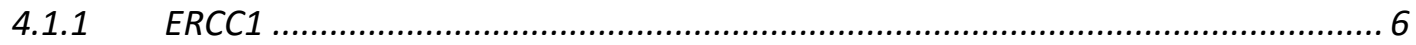

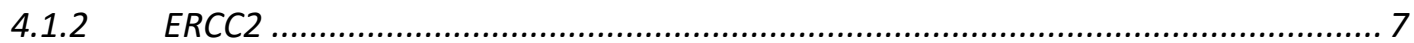

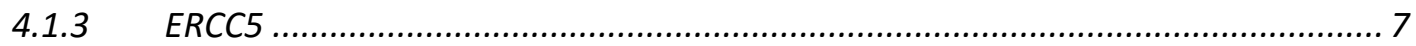

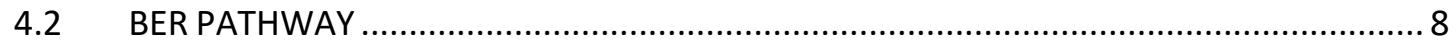

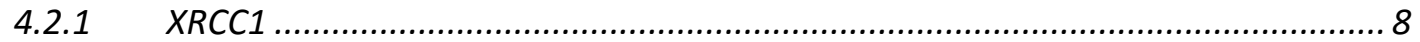

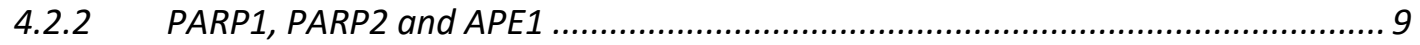

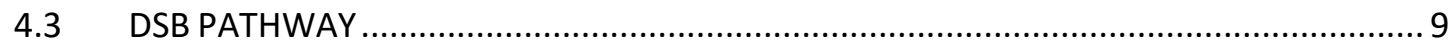

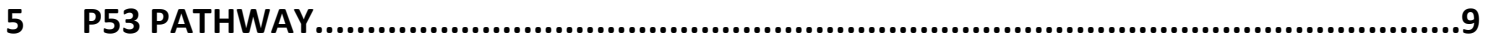

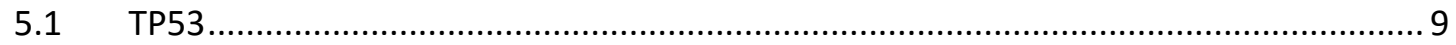

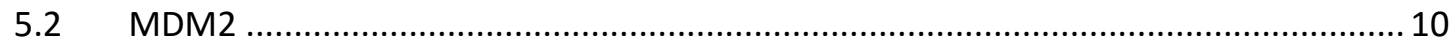

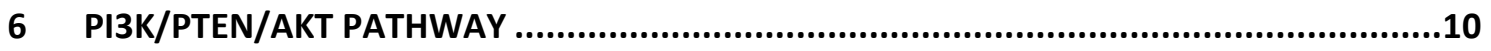

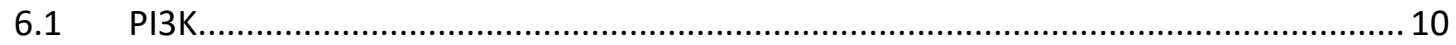

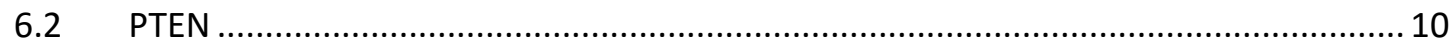

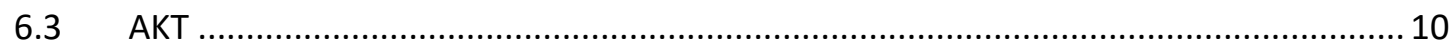

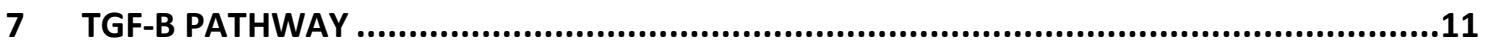

8 CELLULAR EFFLUX TRANSPORTERS .............................................................11

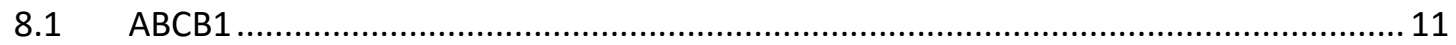

9 GLUTHATHIONE METABOLIC PATHWAY ...................................................11

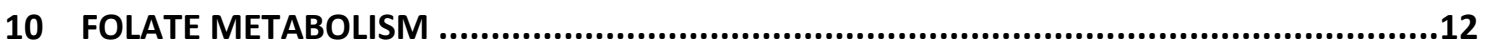

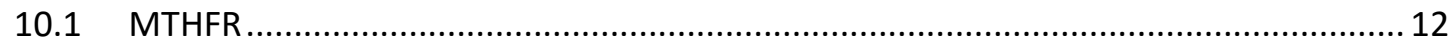

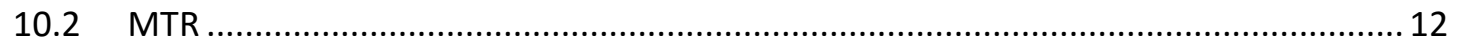

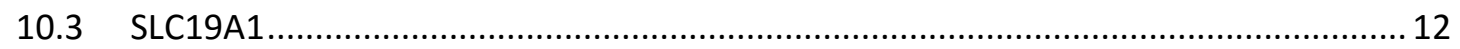

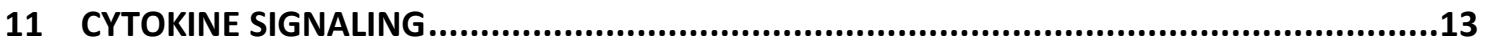

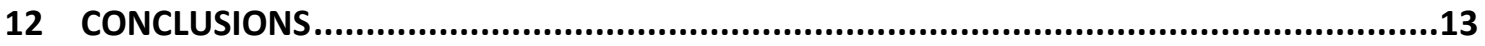

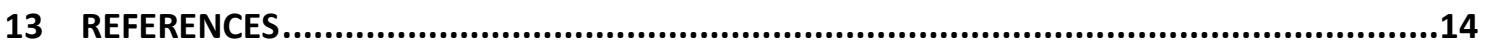

14 FIGURE LEGENDS ........................................ ERROR! BOOKMARK NOT DEFINED. 


\section{TITLE}

CONTRIBUTION OF GENETIC FACTORS TO PLATINUM-BASED CHEMOTHERAPY SENSITIVITY AND PROGNOSIS OF NON-SMALL CELL LUNG CANCER

\section{AUTHORS:}

Cristina Pérez-Ramírez ${ }^{1,2}$, Marisa Cañadas-Garre ${ }^{1}$, Miguel Ángel Molina ${ }^{3}$, Ana I. Robles ${ }^{4}$, María José Faus-Dáder², Miguel Ángel Calleja-Hernández ${ }^{1,6}$.

\section{Author for correspondence:}

2 Marisa Cañadas-Garre, Ph.D.

Pharmacogenetics Unit UGC Provincial de Farmacia de Granada Instituto de Investigación Biosanitaria de Granada Complejo Hospitalario Universitario de Granada Avda. Fuerzas Armadas, 2 18014 Granada, Spain

Telephone: $\quad+34958020108$

Fax: $\quad+34901021804$

Affiliations

E-mail: marisacgarre@gmail.com

\section{Pharmacogenetics Unit}

UGC Provincial de Farmacia de Granada Instituto de Investigación Biosanitaria de Granada Complejo Hospitalario Universitario de Granada Avda. Fuerzas Armadas, 2

Telephone: $\quad+34958020108$

Fax: $\quad+34901021804$

2 Department of Biochemistry Faculty of Pharmacy University of Granada Campus Universitario de Cartuja, s/n 18071 Granada, Spain Telephone: +34958243838

3 Pangaea Biotech, S.L. Hospital Universitario Quirón Dexeus C/ Sabino Arana, 5-19. 08028 Barcelona. SPAIN Tel.: +34 935460135

Fax: +34 935460172

$4 \quad$ National Cancer Institute

37 Convent $\mathrm{Dr}$

37/3060D

Bethesda

Telephone: +1301-496-1729

Fax: +1301-496-0497

5 Department of Pharmacology

Faculty of Pharmacy

University of Granada

Campus Universitario de Cartuja, $\mathrm{s} / \mathrm{n}$

18071 Granada, Spain

Telephone: $\quad+34958243538$ 
Mails

Cristina Pérez-Ramírez Marisa Cañadas-Garre

Miguel Ángel Molina

Ana I. Robles

María José Faus-Dáder

Miguel Ángel Calleja Hernández cperezramirez87@gmail.com

marisacgarre@gmail.com

mamolina@pangaeabiotech.com

Ana_Robles@nih.gov

mfaus@ugr.es

mangel.calleja.sspa@juntadeandalucia.es

Keywords:

PLATINUM BASED CHEMOTHERAPY

NON-SMALL CELL LUNG CANCER

RESPONSE

SURVIVAL

TOXICITY

POLYMORPHISMS

WORD COUNT (excluding references and figure legends):

Abstract: $\quad 134$ words

Main Text: 5088 words

\section{FUNDING}

This work was partly supported by a contract for Marisa Cañadas-Garre (Técnicos de Apoyo Subprogram. CA12/00097) from Instituto de Salud Carlos III, Ministerio de Economía y Competitividad and a research grant for Cristina Pérez-Ramírez (FPU12/04722), from Ministerio de Educación, Cultura y Deporte.

\section{ACKNOWLEDGMENTS}

The results of this investigation are part of the doctoral thesis presented by Cristina PérezRamírez at the University of Granada. 


\section{ABSTRACT}

Although platinum-based chemotherapy remains as a standard treatment for advanced NSCLC patients, the clinical outcomes are poor and most patients develop high-grade toxicities. Genetic factors, such as single nucleotide polymorphisms (SNPs) involved in platinum pharmacodynamics, metabolism and mechanism of action, may account for inter-individual differences shown in effectiveness and toxicity. Polymorphisms in genes involved in DNA repair and others such as PI3K/PTEN/AKT and TGF- $\beta$ pathways have been demonstrated to be associated with response, survival and toxicity in advanced NSCLC patients treated with platinum-based chemotherapy. Other cellular processes, like DNA methylation and proliferation have been connected with clinical outcome for platinum-based chemotherapy regimens through folate metabolism and cytokine signaling.

The influence of gene polymorphisms in the NER pathway on clinical outcome has been extensively investigated in advanced NSCLC patients treated with platinum-based chemotherapy but contradictory results have been reported. The most recent and thorough meta-analyses have failed to show an association between ERCC1 C118T/C8092A and ERCC5 rs1047768 polymorphisms and response to platinum based chemotherapy. However, other polymorphisms in ERCC2 (Lys751Gln and Asp312Asn) and ERCC5 (rs2094258 and rs2296147) and have been related with OS and PFS, respectively. The Arg194Trp and Gln399Arg polymorphisms in XRCC1, have also been extensively investigated. Their effects seem to be dependent on ethnicity, and recent meta-analyses have confirmed an association with response in Asian but not in Caucasian patients. The influence on ORR of the rs861539 polymorphism in XRCC3, a protein of the DSB pathway, has also been confirmed in a metaanalysis.

Finally, SNPs in genes coding proteins of the p53, PI3K, TGF- $\beta$, membrane transporters, gluthatione metabolism enzymes and cytokine pathways have been less extensively investigated. Some polymorphisms have been reported to be associated with toxicity or clinical outcome, but data generally come from a limited number of studies and need to be confirmed.

\section{INTRODUCTION}

Lung cancer represents a serious health problem, being the leading cause of cancer mortality among both men and women worldwide, and is the second tumor in incidence $(\approx 14 \%$; only after prostate cancer in men and breast cancer in women) [1]. In the United States, over 224390 new cases and 158080 deaths are estimated in 2015, according to the latest statistics published [1].

Small cell lung cancer (SCLC) and non-small cell lung cancer (NSCLC) are the main types of lung cancer. NSCLC represents the great majority, with approximately $80 \%$ of all lung cancer cases, and is classified in different subtypes: squamous cell or epidermoid carcinoma, adenocarcinoma and large cell carcinoma. Most patients with NSCLC are diagnosed in an advanced stage (IIIB-IV, according to the American Joint Committee on Cancer) [2-4]. Five-year survival in this stage is poor, with rates of $5 \%$ for IIIB and $1 \%$ for IV stages [2-4].

The standard treatment for advanced or recurrent NSCLC wild-type for the epidermal growth factor (EGFR) gene and not harboring translocations in anaplastic lymphoma receptor tyrosine kinase $(A L K)$ is platinum-based chemotherapy, usually in combination with anti-microtubule agents (taxanes and vinca alkaloids), antifolate agents (pemetrexed), or pyrimidine antagonist (gemcitabine). Although this therapy improves survival in comparison with best supportive care [5], response rates (RR) are less than $32 \%$, progression-free survival (PFS) is around 3.5 months and overall survival (OS) 7.4-11.3 months [6-9]. Furthermore, it is a very aggressive 
treatment with severe side effects according to the Common Terminology Criteria for Adverse Events (CTCAE) Version 4, such as neurotoxic effects (69.9\%) or neutropenia (67.1\%) [10]. Numerous studies have shown that platinum effectiveness and toxicity varies from person to person and that inter-individual differences may be due to genetic factors such as single nucleotide polymorphisms (SNPs) in particular genes [11-17].

Platinum drugs, particularly cisplatin and carboplatin, are heavy metal complexes that exert their antiproliferative effects by inducing DNA damage. They bind covalently to two different sites, either within the same DNA molecule or between two different DNA molecules, generating adducts that inhibit DNA synthesis and transcription and are responsible for severe toxicity of these drugs $[18,19]$. Mammalian cells have different DNA repair pathways to repair DNA damage, including nucleotide-excision repair (NER), base excision repair (BER) and double-strand break repair (DSB) (Figure 1). Several proteins of these pathways, such as excision repair cross-complementing group 1 (ERCC1), excision repair cross-complementation group 2 ( $E R C C 2$, also known as XPD), excision repair cross-complementation group 5 (ERCC5), $\mathrm{X}$-ray repair complementing defective repair in Chinese hamster cells 1 (XRCC1) and X-ray repair complementing defective repair in Chinese hamster cells 3 (XRCC3), are involved in the detection and repair of the adducts and cross-links induced by platinum activity $[20,21]$. The p53 pathway also plays an essential role in DNA repair, together with cell cycle control and apoptosis initiation in response to DNA damage [22]. The MDM2 proto-oncogene, E3 ubiquitin protein ligase (MDM2) modulates the activity of the pathway through directing binding, ubiquitination and degradation of p53 [23]. Numerous studies have reported that SNPs in any of these genes may regulate the DNA repair functions in the normal and tumor cells, contributing to individual variation in the response and toxicity to platinum-based chemotherapy [11-16,24-27].

Although DNA repair pathways are the key players in platinum toxicity and response, other pathways and proteins are also involved, including the phosphatase and phosphatidylinositol 3-kinase / tensin homolog / v-akt murine thymoma viral oncogene (PI3K/PTEN/AKT) pathway, the transforming growth factor beta (TGF- $\beta$ ) and cytokine signaling pathways, drug transporters, detoxification systems and folate metabolism enzymes. Genetic alterations in genes of the PI3K/PTEN/AKT and TGF- $\beta$ pathways may modify signaling and have an impact in the development of toxicity or disease progression to platinum-based therapies [28-32]. Polymorphisms in ATP-binding cassette, sub-family B (MDR/TAP), member 1 ( $A B C B 1$, also called MDR1) have also been suggested as predictive markers of response and side effects to platinum therapy [33-35]. ABCB1 gene is an cell membrane transporter [36], involved in the ATP dependent export of chemicals out of cell [37-39] that modulates response and toxicity by impairing the intracellular retention of multiple anticancer drugs $[40,41]$. Detoxification of platinum compounds is mediated by glutathione S-transferase Pi 1 (GSTP1); gene polymorphisms in this enzyme has been correlated with clinical outcome and toxicity of platinum therapy [42-49]. Methylenetetrahydrofolate reductase (MTHFR), methionine synthase (MTR) and solute carrier family 19 (folate transporter), members 1 (SLC19A1) are involved in folate metabolism [50-54]. Genetic alterations in these genes disturb methylation of DNA, which may influence the effectiveness and toxicity of platinum-based chemotherapy $[17,55-57]$. Cytokine signaling regulates tumor progression by promoting angiogenesis, cell growth and differentiation of tumoral cells [58]. Finally, gene polymorphisms in interleukin 1B (IL1B), 6 (IL6), 12A (IL12A), 13 (IL13), 16 (IL16) have also been associated with survival to platinum-based chemotherapy $[59,60]$.

In this review, we will discuss briefly the most relevant gene polymorphisms related with clinical outcomes and toxicity of platinum therapy in NSCLC patients. 


\section{DNA REPAIR PATHWAYS}

Genetic alterations in DNA repair genes can modify individual responses and toxic side effects to platinum-based chemotherapy. Four main DNA repair pathways are utilized by the cells: NER, BER, DBS and MMR (mismatch repair). NER, BER, and DBS are the main repair pathways in the removal of DNA lesions produced by platinum compounds [20,21]. MMR is not directly involved in repair of platinum adducts. It recognizes DNA adducts and activates apoptosis [61]. All of them are regulated by $\mathrm{p53}$, which can trigger cell cycle arrest and DNA repair or apoptosis (Figure 1) [62-65].

\subsection{NER PATHWAY}

The NER pathway, through ERCC1, ERCC2 and ERCC5 genes, is able to repair helix-distorting DNA lesions, which prevent base pairing, blocking transcription and normal replication [66-68].

\subsubsection{ERCC1}

ERCC1 is the key enzyme in the NER pathway [66]. It heterodimerizes with excision repair cross-complementation group 4 (ERCC4 also called XPF), and the resultant ERCC1/ERCC4 complex makes an incision at the $5^{\prime}$ end of the lesion, allowing removal of the damaged DNA strand and further polymerization and religation $[66,68]$.

Two polymorphisms in ERCC1; rs11615 ( $\rightarrow$ T synonymous substitution at codon 118, exon 4, Asn $\rightarrow$ Asn, C118T) and rs3212986 ( $\rightarrow$ A substitution in the $3^{\prime}$-untranslated region, C8092A); have been extensively investigated in advanced NSCLC patients treated with platinum-based chemotherapy (Table 1) [44,49,69-88]. The possible mechanisms underlying the effects of these base changes in platinum therapy effectiveness and toxicity by is still unclear. Several studies have described some effects on ERCC1 mRNA expression, whereas others have found no association [89-91].

Regarding ERCC1 C118T, its association with clinical outcome to platinum-based chemotherapy remains unclear (Table 1) $[13,24,44,49,69-88,92-100]$, with some studies reporting better overall response rate (ORR) in patients carrying the $C$ allele $[49,69-72]$, and others in patients with the TT genotype [44,73-77]. Six meta-analyses have evaluated the influence of ERCC1 C118T polymorphism $[11-13,33,101,102]$ and the two largest (23 studies/3231 patients and 21 studies/1281 patients, respectively), have not found any association between the ERCC1 C118T polymorphism and ORR (OR=0.94; $\mathrm{Cl}_{95 \%}=0.72,1.23 ; \mathrm{I}^{2}=60 \%$; $\mathrm{P}_{\text {heterogeneity }}<0.01 ; \mathrm{CT} / \mathrm{TT}$ vs $\mathrm{CC}$ and OR=0.95; $\mathrm{Cl}_{95 \%}=0.85,1.06 ; \mathrm{I}^{2}=66.90 \% ; P_{\text {heterogeneity }}=0.386 ; \mathrm{CT} / \mathrm{TT}$ vS CC) $[13,102]$. The same contradictory results have been reported in the case of PFS and OS, with some studies finding an association of the CC genotype with a better outcome and others reaching opposite conclusions $[13,49,70,72,75,77-84,96]$. Finally, a meta-analysis including 13 studies, found a significant association of ERCC1 C118T polymorphism with a longer OS (OR=1.26; $\mathrm{Cl}_{95 \%}=1.02$, $1.55 ; I^{2}=67 \%$; $P_{\text {heterogeneity }}<0.01 ; C T / T T$ vs $\left.C C\right)$ but not with PFS (OR=1.23; $\mathrm{Cl}_{95 \%}=0.90,1.69$; $\mathrm{I}^{2}=70.7 \%$; $\mathrm{P}_{\text {heterogeneity }}<0.01 ; \mathrm{CT} / \mathrm{TT}$ vs $\mathrm{CC}$ ) [13].

The ERCC1 C8092A polymorphism has also been associated with response in two studies in 115 and 163 Asian patients, which reported worse ORR to platinum-based chemotherapy in patients carrying the A allele $\left(\mathrm{OR}=0.23\right.$; $\mathrm{Cl}_{95 \%}=0.10,0.57$ for $\mathrm{AC} / \mathrm{AA}$ vs $\mathrm{CC}$ and $\mathrm{OR}=0.44$; $\mathrm{Cl}_{95 \%}=0.27,0.74$ for A vs $C$ allele, respectively) $[72,73]$. Studies in Caucasian population have not found significant associations between ERCC1 C8092A polymorphism and outcome in advanced NSCLC patients $[76,87,88,99]$ and four meta-analyses have reached the same conclusion; the largest one, a meta-analysis carried out with 10 studies and 1311 patients also failed to show influence of this polymorphism on response to platinum-based chemotherapy (OR=1.05; $\mathrm{Cl}_{95 \%}=0.83,1.32 ; \mathrm{I}^{2}=39.3 \% ; P_{\text {heterogeneity }}=0.096 ; \mathrm{AC} / \mathrm{AA}$ vs CC) [13]. Regarding OS and $\mathrm{PFS}$, results for ERCC1 C8092A are again contradictory, with some reports associating the CC 
genotype with better $[72,77,80,85,86]$ and worse OS and PFS $[87,88]$. A recent meta-analysis, including 6 studies and 999 cases, could not find any significant association between the polymorphism and OS (HR=1.26; $\mathrm{Cl}_{95 \%}=0.81,1.95 ; I^{2}=87 \%$; $P_{\text {heterogeneity }}=<0.01 ; A C / A A$ vs CC) [13].

Finally, although the association between toxicity and ERCC1 polymorphisms has also been extensively investigated, no significant findings have been reported (Table 1) $[49,76,79,87,88,91,103-111]$.

\subsubsection{ERCC2}

The ERCC2 protein is a component of the general transcription factor IIH (TFIIH) and its helicase activity plays a key role gene transcription and nucleotide excision repair [67].

Numerous SNPs in ERCC2 gene have been described, being $\mathrm{rs} 13181$ ( $\mathrm{A} \rightarrow \mathrm{C}$ substitution at codon 751, exon 23, Lys $\rightarrow$ GIn) and $r s 1799793$ ( $G \rightarrow$ A substitution at codon 312, exon 10, Asp $\rightarrow$ Asp) the most investigated. Although both SNPs cause suboptimal DNA repair capacity $[112,113]$, no significant association has been found between ERCC2 Lys751GIn or Asp312Asn and ORR or PFS (Table 2) $[24,49,73,74,76,79,82,84,87,88,91-93,98,99,104,105,109,114-125]$. This lack of association has been confirmed in two recent meta-analyses, including 22 studies/3240 patients [13] and 12 studies/1737 patients [102]. In contrast, several studies have found an association between OS and both SNPs $[49,98,118,120]$. The genotype CC for ERCC2 Lys751GIn polymorphism has been correlated with a longer OS compared to the AC/AA genotypes in Asian population (HR=1.54; $\mathrm{Cl}_{95 \%}=1.03,2.29$; $\mathrm{AC} / \mathrm{AA}$ vs $\mathrm{CC}$ ) [118]. In the case of Asp312Asn, the AG/AA genotype has been associated with poor survival both in Caucasian and Asian populations (Table 2) $[49,98,118,120]$. A meta-analysis has also confirmed these results in Asian ( $\mathrm{HR}=2.07 ; \mathrm{Cl}_{95 \%}=1.11,3.88 ; \mathrm{AG} / \mathrm{AA}$ vs $\mathrm{GG}$ ) but not in Caucasian population ( $\mathrm{HR}=0.84$; $\mathrm{Cl}_{95 \%}=0.62$, 1.14; AG/AA vs GG) [13].

An relationship between ERCC2 Asp312Asn and Lys751GIn and hematological toxicity has been reported in two small studies including 55 and 62 patients $[79,107]$, with A-allele for ERCC2 Lys751GIn associating with increased grade 2-3 neutropenia $(p=0.04)$ [79] and the Gallele Asp312Asn with a reduced frequency of severe hematological toxicity $(O R=0.08$; $\mathrm{Cl}_{95 \%}=0.01,0.40 ; \mathrm{p}=0.0005 ; \mathrm{AG} / \mathrm{GG}$ vs AA) [107]. The AA genotype for ERCC2 Lys751Gln has also been associated with higher risk of severe nephrotoxicity $\left(\mathrm{OR}=0.07 ; \mathrm{Cl}_{95 \%}=0.02,0.31\right.$; $A C / C C$ vs AA) [107]. Other studies in larger patient populations (65 to 493) failed to find such associations between ERCC2 polymorphisms and platinum-based chemotherapy toxicity (Table 2) $[49,76,87,88,91,104,105,109,110,117,118,124,126]$.

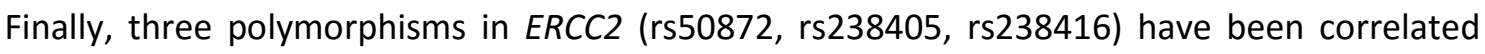
with clinical outcomes in a cohort 1290 Asian advanced NSCLC patients [127], with rs50872 associated with longer OS ( $p=0.009)$ and PFS ( $p=0.032)$ in all patients, $r 238405$ in patients treated with a combination of platinum and taxanes and rs 238416 in those receiving platinum and gemcitabine doublets [127].

\subsubsection{ERCC5}

The ERCC5 gene encodes a single-strand specific DNA endonuclease, which cleaves the damaged DNA strand 3 ' to the lesion during nucleotide excision repair [128].

The $T T$ genotype in the ERCC5 rs 1047768 polymorphism ( $T \rightarrow C$ substitution at codon 46 , exon 2 , $\mathrm{His} \rightarrow \mathrm{His}$ ) has been associated with increased ORR (OR=1.90; $\mathrm{Cl}_{95 \%}=1.10,3.28$; TT vs CC), OS ( $\mathrm{HR}=0.52 ; \mathrm{Cl}_{95 \%}=0.31,0.96 ; \mathrm{TT}$ vs $\mathrm{CC}$ ) and PFS (HR=0.47; $\left.\mathrm{Cl}_{95 \%}=0.22,0.82 ; \pi \mathrm{Ts} \mathrm{CC}\right)$ [129]. A meta-analysis which included 5 studies with 846 cases, has recently confirmed these results for

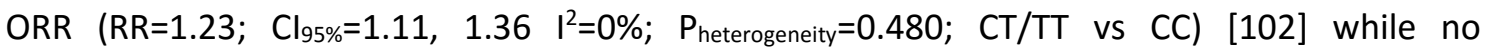
association of rs1047768 with toxicity was found in 74 Spanish NSCLC patients [76]. In 
contrast, ERCC5 rs17655 polymorphism ( $\mathrm{G} \rightarrow$ C substitution at codon 1104, exon 15, Asp $\rightarrow$ His) has been related with a higher infection rate $(p=0.017)$ in 388 Chinese NSCLC patients [130] but not with clinical outcome (Table 3) [76,84,93,131-133].

Three additional polymorphisms in ERCC5 (rs2094258, rs2296147, rs873601) have also been investigated. The G-allele for ERCC5 rs2094258 has been associated with increased OS ( $\mathrm{HR}=0.51 ; \mathrm{Cl}_{95 \%}=0.39,0.82 ; \mathrm{AG} / \mathrm{GG}$ vs AA) and PFS ( $\mathrm{HR}=0.44 ; \mathrm{Cl}_{95 \%}=0.34,0.78 ; \mathrm{AG} / \mathrm{GG}$ vs AA) in 433 advanced NSCLC patients treated with platinum-based chemotherapy [133]. In the case of ERCC5 rs2296147, two studies in 433 and 277 Chinese patients found a significant association with OS (HR=0.66; $\mathrm{Cl}_{95 \%}=0.48,0.99$ for $\mathrm{CT} / \mathrm{TT}$ vs $\mathrm{CC}$ and $\mathrm{HR}=0.49 ; \mathrm{Cl}_{95 \%}=0.36,0.68$ for T vs $\mathrm{C}$ allele) and PFS (HR=0.73; $\mathrm{Cl}_{95 \%}=0.51,0.97$ for $\mathrm{CT} / \mathrm{TT}$ vs $\mathrm{CC}$ and $\mathrm{HR}=0.52 ; \mathrm{Cl}_{95 \%}=0.38,0.70$ for $\mathrm{T}$ vs $C$ allele) $[131,133]$. Finally, the allele $G$ of the $r s 873601$ polymorphism correlated with a better OS (HR=0.84; $\mathrm{Cl}_{95 \%}=0.64,1.09 ; \mathrm{G}$ vs A allele) in 277 Chinese stage III/IV NSCLC patients [131].

\subsection{BER PATHWAY}

The BER pathway removes small, non-helix-distorting base lesions from the genome, including single strand breaks produced by oxidation, methylation, deamination and hydroxylation [134]. These lesions may not block transcription and normal replication, but they usually cause miscoding. In this process, the enzymes poly (ADP ribose) polymerase 1 and 2 (PARP1 and PARP2) play a key role, along with apurinic/apyimidinic endonuclease 1 (APE1) and XRCC1 $[135,136]$.

\subsubsection{XRCC1}

The XRCC1 protein interacts with DNA polymerase-beta, DNA ligase III and PARP (poly ADPribose polymerase), repairing the damaged DNA strand [137].

$X R C C 1$ rs1799782 ( $\rightarrow$ G substitution at codon 194, exon 6, Arg $\rightarrow \operatorname{Trp})$ and $r s 25487$ ( $A \rightarrow G$ substitution at codon 399, exon 10, Gln $\rightarrow$ Arg) polymorphisms are the most studied. The Tallele for XRCC1 Arg194Trp has been associated with better ORR in Asian population, but not in Caucasian patients (Table 4) [76,107,132,138-141]. A recent meta-analysis, which involved 11 studies and compiled 1329 cases, has reported similar results in Asian population (OR=0.38; $\mathrm{Cl}_{95 \%}=0.30,0.48 ; \mathrm{I}^{2}=0 \%$; Pheterogeneity $=0.830 ; \mathrm{CT} / \mathrm{TT}$ vs CC) [15]. For XRCC1 Gln399Arg, several studies in Asian population have found a relationship between genotype GG and higher ORR (Table 4) $[47,97,140,142]$. This result has been confirmed by a recent meta-analysis, which evaluated 13 studies and 1334 cases from Asian population (OR=2.05; $\mathrm{Cl}_{95 \%}=1.62,2.60 ; \mathrm{I}^{2}=26 \%$; $P_{\text {heterogeneity }}=0.18$; GG vs AG/AA) [15]. However, more recent studies in 325 and 147 Chinese patients have reported poor ORR for GG genotype $[43,143]$. No significant association has been reported in Caucasian population (Table 4) [49,76,87,88,99,121].

The XRCC1 Gln399Arg polymorphism has also been associated with OS, PFS and toxicity $[42,43,47,99,107,144]$. A longer OS for the AA genotype has been reported in two studies in Asian (OR=1.69; $\mathrm{Cl}_{95 \%}=1.19,2.39$ for $\mathrm{GG}$ vs $A G / A A$ and $O R=0.17 ; \mathrm{Cl}_{95 \%}=0.06,0.41$ for $A A$ vs $G G$ ) and one in Caucasian populations ( $O R=0.47 ; \mathrm{Cl}_{95 \%}=0.23,0.95$ for $A$ vs $\mathrm{G}$ allele) $[43,99,144]$. The GG genotype showed significant results for PFS in 114 stage-IV NSCLC patients (OR=1.768; $\mathrm{Cl}_{95 \%}=1.14,2.73$ for AG/AA vs GG) [47] and has also been linked with increased hematological (OR=0.323; $\mathrm{Cl}_{95 \%}=0.121,0.862$ for $\mathrm{AG} / \mathrm{AA}$ vs $\mathrm{GG}$ and $\mathrm{OR}=0.22 ; \mathrm{Cl}_{95 \%}=0.06,0.82$ for $\mathrm{AG} / \mathrm{AA}$ vs $\mathrm{GG}$ ) and gastrointestinal toxicity (OR=0.298; $\mathrm{Cl}_{95 \%}=0.108,0.825$ for $\mathrm{AG} / \mathrm{AA}$ vs GG) $[42,107,144]$. In contrast, other study reported higher incidence of hematological toxicity for $A A / A G$ genotype ( $O R=2.135 ; \mathrm{Cl}_{95 \%}=1.207,3.777$ for $A G / A A$ vs $G G$ ) [144]. Finally, no associations between OS, PFS, toxicity and XRCC1 Arg194Trp SNPs have been found (Table 4) $[43,76,107,119,129,143,145,146]$. 


\subsubsection{PARP1, PARP2 and APE1}

The role of PARP1, PARP2 and APE1 polymorphisms on clinical outcomes to cisplatin in advanced NSCLC has been less investigated. The T-allele for APE1 rs1760944 polymorphism was found to be associated with gastrointestinal toxicity in 235 patients [144], and the GG genotype for APE1 rs3136820 showed better OS compared to the TT genotype in 147 patients $\left(\mathrm{HR}=0.33 ; \mathrm{Cl}_{95 \%}=0.12,0.92\right)$ [143]. A polymorphism in PARP1 ( $\left.\mathrm{s} 1136410\right)$ has also been associated with survival; in particular, patients with CC genotype showed lower PFS than CT/TT patients (HR=1.90; $\left.\mathrm{Cl}_{95 \%}=1.02-3.52\right)$ [143]. Finally, no studies have evaluated polymorphisms in $P A R P 2$ and their associations with clinical outcomes or toxicity.

\subsection{DSB PATHWAY}

The DSB pathway is involved in repairing the most severe lesions, affecting both strands, which may result in cell death or a diversity of genetic alterations, such as deletions and chromosomal aberrations [147]. Homologous recombination (HR) and non-homologous endjoining (NHEJ) are the two main mechanisms of the DSB pathway [147]. Key proteins involved are MRE11 (MRE11 homolog A, double strand break repair nuclease), NBN (nibrin) and RAD50 (RAD50 double strand break repair protein), which form the MRE11 complex, BRCA1 (breast cancer 1), BRCA2 (breast cancer 2), RAD51 (RAD51 recombinase) and XRCC3 $[147,148]$. Despite of the essential function of these proteins in DSB pathway, only a polymorphism in XRCC3 gene has been extensively studied $[49,84,92,98,99,105,106,110,117,149-152]$.

The $C \rightarrow T$ substitution at codon 241, exon 7 of XRCC3 (Thr $\rightarrow$ Met, rs861539) has been associated with ORR and OS, but not with PFS or toxicity (Table 5) $[49,84,98,99,105,106,110,117,149-152]$ The genotype CT/TT has shown higher ORR (OR=2.72; $\mathrm{Cl}_{95 \%}=1.17,6.31$ for $\mathrm{CT} / \mathrm{TT}$ vs CC) in 137 Caucasian stage III-IV NSCLC patients [49], a result confirmed by a meta-analysis that included 7 studies and 1186 patients (OR=1.51; $\mathrm{Cl}_{95 \%}=1.10$, 2.07; $I^{2}=0 \%$; $P_{\text {heterogeneity }}=0.618 ; C T / T T$ vs CC) [16]. The TT genotype has also been associated with prolonged OS in 135 Caucasian stage III-IV NSCLC patients (OR=0.43; $\mathrm{Cl}_{95 \%}=0.22,0.82$ for TT vs CC) [92].

\section{P53 PATHWAY}

The TP53 tumor suppressor gene regulates the DNA repair through its ability to act as a transcription factor and to interact with damaged DNA, promoting the activation of DNA repair mechanisms $[153,154]$. In addition, TP53 may induce apoptosis, arresting the cell cycle progression, when DNA damage is extensive $[155,156]$ (Figure 1).

\section{$5.1 \quad$ TP53}

The TP53 tumor suppressor gene has a prominent role in carcinogenesis [156]. It has an anticancer function, inhibiting angiogenesis, inducing apoptosis of tumor cells and maintaining genomic stability [156]. This gene is frequently somatically mutated in NSCLC (40-70\%), which may modify p53 activity and induce resistance to platinum based chemotherapy [157].

In tumor cell lines with a wild type TP53 gene, the GG genotype of a common TP53 polymorphism located at codon 72 , exon 4 ( $C \rightarrow G$, rs1042522, Pro72Arg), enhances the risk of death by promoting the mitochondrial localization of p53 [158]. When the p53 protein is mutated, the polymorphism has the opposite effect $[159,160]$. In NSCLC patients treated with platinum compounds, the $\mathrm{p} 53$ mutant protein with GG genotype has been described to abolish the function of p73, a related p53 protein, and therefore inhibit apoptosis [24]. The CC genotype has shown better response (OR=3.02; $\mathrm{Cl}_{95 \%}=1.77,5.18 ; \mathrm{CC}$ vs $\mathrm{GG}$ ) in $640 \mathrm{NSCLC}$ patients treated with platinum compounds [24] while the GG variant has been associated with higher gastrointestinal toxicity (OR=0.24; $\mathrm{Cl}_{95 \%}=0.076,0.810$ for $\mathrm{GC} / \mathrm{CC}$ vs GG) (Table 6) [25]. 


\subsection{MDM2}

The MDM2 protein is a negative regulator of $\mathrm{p} 53$ that binds to the $\mathrm{p} 53$ protein inducing its ubiquitination and degradation [23]. Two polymorphisms in MDM2 ( $\mathrm{C} \rightarrow \mathrm{T}$, rs1470383 and $A \rightarrow G, r s 1690924)$ have been associated with gastrointestinal and hematological toxicity, but not with OS and PFS in 663 Chinese NSCLC patients (Table 6) [27]. Patients with the AA genotype for MDM2-rs1470383 showed lower hematological chemotherapy-related toxicity than those with the GG genotype (OR=4.10; $\mathrm{Cl}_{95 \%}=1.73,9.71$ for $\mathrm{GG}$ vs $\left.\mathrm{AA}\right)$ [27]. In contrast, the GG genotype for MDM2 rs1690924 has been related to lower gastrointestinal toxicity $\left(\mathrm{OR}=2.32 ; \mathrm{Cl}_{95 \%}=1.30,4.14\right.$ for $\mathrm{AG}$ vs $\mathrm{AA}$ ) (Table 6) [27]. The relationship between these SNPs with response has not been evaluated.

An association has also been found between a SNP in the promoter region of MDM2 (T $\rightarrow \mathrm{G}$, rs2279744) and clinical outcomes in NSCLC patients treated with cisplatin/carboplatin $[25,26]$. The GG genotype correlated with longer OS (HR=1.33; $\mathrm{Cl}_{95 \%}=1.03,1.72$ for GT/TT vs GG) in 568 NSCLC patients [26] and lower hematological toxicity in 444 Chinese advanced NSCLC patients (OR=2.18; $\mathrm{Cl}_{95 \%}=1.12,4.25$ for $\mathrm{GT} / \mathrm{TT}$ vs $\mathrm{GG}$ ) [25].

\section{PI3K/PTEN/AKT PATHWAY}

The PTEN/PI3K/AKT signaling is involved in a great variety of cell processes, such as cell proliferation and survival, which may be altered by polymorphisms in the genes that integrate the pathway [161].

\subsection{PI3K}

The PI3K enzyme catalyzes the conversion of PIP2 into PIP3, activating the downstream AKT signaling [162]. Despite of this key role, none of the polymorphisms studied to date in the PI3K gene ( $A \rightarrow G$, rs7651265; $C \rightarrow G, r s 7640662 ; T \rightarrow C$, rs7621329, $A \rightarrow C$ rs6443624; $G \rightarrow A, r s 2699887)$ have shown a significant association with clinical outcomes in NSCLC patients treated with platinum based chemotherapy [28]. Only the AA genotype for rs2699887 has been correlated with increased grade 3-4 toxicity in 168 Caucasian stage IIIB/IV NSCLC patients (OR=3.86; $\mathrm{Cl}_{95 \%}=1.08,13.82$ for $\mathrm{GG}$ vs AA) [28].

\subsection{PTEN}

PTEN, a well-known tumor suppressor gene, codifies a protein phosphatase that hydrolyzes PIP3 and inhibits the PTEN/PI3K/AKT pathway $[163,164]$.Three polymorphisms in PTEN $(T \rightarrow A / C, r s 2299939 ; T \rightarrow G$ rs12569398, G $\rightarrow C$ rs12557281) have been evaluated, and only the AA genotype in rs2299939 has been associated with severe toxicity in 168 Caucasian stage IIIB/IV NSCLC patients (OR=0.44; $\mathrm{Cl}_{95 \%}=0.20,0.95$ for $A C / C C$ vs $\left.A A\right)$ [28]. The influence of these SNPS on ORR, PFS and OS has not been determined.

\section{$6.3 \quad$ AKT}

The AKT protein is the main downstream target of PI3K pathway. It triggers the phosphorylation of a series of intermediates effectors, promoting cell cycle progression, cell proliferation, transcription and cell migration [165-167].

The T allele in the AKT polymorphisms rs3803304 and rs2498804 have been associated with longer PFS in advanced NSCLC patients treated with cisplatin-based chemotherapy (HR $=0.66$; $\mathrm{Cl}_{95 \%}=0.45,0.97$ for $\mathrm{CT} / \mathrm{TT}$ vs $\mathrm{CC}$ and $\mathrm{HR}=0.52 ; \mathrm{Cl}_{95 \%}=0.35,0.77$ for $\mathrm{GT} / \mathrm{TT}$ vs $\mathrm{GG}$, respectively) [28]. In contrast, the GG genotype of AKT rs 1130214 have been correlated with shorter PFS in 168 advanced NSCLC patients (HR=0.62; $\mathrm{Cl}_{95 \%}=0.42,0.91$ for $\mathrm{GT} / \mathrm{TT}$ vs GG) [28], while it was associated with better OS (HR=2.78; $\mathrm{Cl}_{95 \%}=1.11,6.99$ for TT Vs GG) and PFS (HR=1.48; $\mathrm{Cl}_{95 \%}=1.02,2.15$ for $\mathrm{TT}$ vs GG) in 310 early NSCLC patients receiving cisplatin-based adjuvant 
therapy [168]. No association with toxicity has been described in any polymorphism, and ORR has not been evaluated [28].

\section{TGF- $\beta$ PATHWAY}

The TGF- $\beta$ pathway regulates tumorigenesis and tumor progression through its effects on cellular proliferation, survival, angiogenesis and invasion, via cross talk with SMAD transcriptional regulators [32].

The CT/TT genotypes for the SMAD3 polymorphisms rs6494633 and rs11632964 have been associated with better OS ( $\mathrm{HR}=1.20 ; \mathrm{Cl}_{95 \%}=1.01,1.43$ for $\mathrm{CC}$ vs $\mathrm{CT} / \mathrm{TT}$ and $\mathrm{HR}=1.52 ; \mathrm{Cl}_{95 \%}=1.05$, 2.17 for CC vs CT/TT, respectively) in 598 Caucasian stage IIIA/IV NSCLC patients [29]. In contrast, polymorphisms in TGF- $\beta$ receptor do not seem to be associated with response and survival to platinum based chemotherapy [29].

\section{CELLULAR EFFLUX TRANSPORTERS}

Proteins involved in drug efflux are responsible of extruding drugs out of the cell $[36,40,41]$ and polymorphisms in the corresponding genes have been associated with efficacy of platinum based chemotherapy in advanced NSCLC.

\subsection{ABCB1}

$A B C B 1$ is the most extensively studied transmembrane cellular efflux transporter. It belongs to the ATP-binding cassette family, and pumps out the cell an enormous variety of drugs, including platinum compounds $[36,40,41]$. Polymorphisms in this gene lead to lower expression and activity of $A B C B 1$ protein, increasing levels of drugs outside the cells [169]. Contradictory results have been obtained when analyzing the association of the silent polymorphism rs1045642, ( $C \rightarrow$ T substitution at codon 1142, exon 26, position 3435, C3435T) [169], with ORR to platinum drugs in advanced NSCLC (Table 7) $[74,79,103,109,170-172]$. Although a meta-analysis, including 5 studies with a total of 379 Asian and Caucasian patients, reported higher ORR for the $\mathrm{CC}$ variant $\left(\mathrm{OR}=1.82 ; \mathrm{Cl}_{95 \%}=1.17,2.85 ; \mathrm{I}^{2}=0 \%\right.$; $\mathrm{P}_{\text {heterogeneity }}=0.77$; $\mathrm{CC}$ vs $\mathrm{CT} / \mathrm{TT}$ ) [33]. The $\mathrm{C}$-allele has also been associated with better OS (HR=0.77; $\mathrm{Cl}_{95 \%}=1.11,6.99$ for $\mathrm{C}$ vs T allele) and PFS (HR=0.62; $\mathrm{Cl}_{95 \%}=0.38,1.00$ for $\mathrm{C}$ vs $\mathrm{T}$ allele) in two studies including 160 and 94 advanced NSCLC patients, respectively [34,109]. A correlation with grade 3-4 gastrointestinal toxicity was also initially reported in 62 stage IIIB-IV NSCLC patients $(p=0.03)$ [79], but in further studies failed to confirm it $[35,103,109]$.

A meta-analysis in Asian population, with a total of 3 studies and 96 patients, has reported better ORR for the GG variant $\left(\mathrm{OR}=2.61 ; \mathrm{Cl}_{95 \%}=1.44,4.74 ; \mathrm{I}^{2}=0 \%\right.$; $P_{\text {heterogeneity }}=0.51 ; \mathrm{GG}$ vs GT/GA/TT/AA) of a polymorphism in linkage disequilibrium with C3435T SNP (Ala893Ser, rs2032582), which modifies the expression of the ABCB1 protein $[33,103]$. In contrast, no significant association with toxicity was reported and PFS and OS were not evaluated (Table 7) [103].

Finally, contradictory reports have also been published regarding the silent SNP rs1128503 (Gly412Gly) The C-allele was associated with longer OS (HR=1.53; $\mathrm{Cl}_{95 \%}=1.11,2.09$ for $\mathrm{C}$ vs $\mathrm{T}$ allele) and PFS (HR=2.04; $\mathrm{Cl}_{95 \%}=1.11,3.77$ for $\mathrm{C}$ vs T allele) in 160 stage III-IV NSCLC patients [34] while an analysis of 86 stage IIIB-IV NSCLC patients reported shorter PFS for CC genotype ( $\mathrm{HR}=0.541 ; \mathrm{Cl}_{95 \%}=-1.112,-0.117$ for $\mathrm{CT} / \mathrm{TT}$ vs $\mathrm{CC}$ ) in [35]. No association with toxicity was found and ORR was not studied.

\section{GLUTHATHIONE METABOLIC PATHWAY}

The glutathione metabolic pathway mediates platinum detoxification through glutathione conjugation [173]. Glutathione S-transferase (GSTPs) enzymes catalyze this process. The major subclasses of GSTs are GSTM1, GSTP1, GSTT1, and GSTA1 [174]; being GSTP1 the most 
abundant isoform in the lung and the enzyme mainly involved in platinum detoxification in NSCLC patients $[175,176]$. A single nucleotide substitution at exon 5 ( $G \rightarrow A$, rs1695, lle105Val) has been demonstrated to alter GSTP1 activity [177], with the Val variant being more active against cisplatin and carboplatin compounds $[47,49,178]$. Several studies have reported that the AG/GG genotypes in rs 1695 are associated with better ORR, PFS and OS (Table 8) [42-47] and that the GG genotype correlates with less severe hematological toxicity $(p=0.02)$, but higher neurotoxicity $(p=0.01)[48,49]$.

\section{FOLATE METABOLISM}

Folate metabolisms is involved in various intracellular processes such as DNA methylation, cell proliferation and synthesis of nucleic and amino acids [179]. Genetic alterations in these genes may disrupt folate metabolism function, inducing DNA hypomethylation and consequently activating proto-oncogenes [180-184]. Thus, polymorphisms in folate metabolism genes may promote tumor development and modify sensitivity of tumor cells to platinum compounds.

\subsection{MTHFR}

MTHFR is a crucial enzyme in the folate metabolism. Several polymorphisms in this gene lead to a production of an enzyme with decreased activity and their effects have been linked with DNA hypomethylation, therefore influencing platinum therapy outcomes [180-184].

A C $\rightarrow$ T transition at codon 222, exon 4 ( $V a l \rightarrow A l a, ~ r s 1801133)$ has been found to be associated with response, survival and toxicity of platinum compounds drugs. A meta-analysis compiling data from 3 studies and 147 patients, both in Asian and Caucasian populations, has shown better response in individuals with $T$ genotype $\left(\mathrm{OR}=1.72 ; \mathrm{Cl}_{95 \%}=1.01,2.93 ; \mathrm{I}^{2}=16 \%\right.$; $P_{\text {heterogeneity }}=0.31$; TT vs CT/CC) [17]. The TT variant has also been associated with higher OS $(p=0.026)$ and PFS $(p=0.012)$ in 208 Italian stage IIIB/IV NSCLC patients (Table 9) [122]. Likewise, the genotype $\mathrm{CC}$ has been correlated with higher hematological toxicity in 1004 Chinese stage III/IV NSCLC patients (OR=0.40; $\mathrm{Cl}_{95 \%}=0.19,0.85$ for CT vs CC) (Table 9) [185].

Another polymorphism in MTHFR, which results in an $A \rightarrow C$ substitution at codon 429, exon 7 (Glu $\rightarrow$ Ala, rs1801131), has also been associated to platinum based chemotherapy outcomes [185]. Carriers of AA genotype presented lower ORR (OR=1.52; $\mathrm{Cl}_{95 \%}=1.04,2.23$ for AC vs AA), PFS $(p=0.03)$ and higher gastrointestinal toxicity in a study conducted in 1004 Chinese stage III/IV NSCLC patients (OR=0.40; $\mathrm{Cl}_{95 \%}=0.22,2.23$ for AC vs AA) (Table 9) [185].

\subsection{MTR}

MTR is an important vitamin B12-dependent enzyme, which catalyzes the final step in folate metabolism [50].

A transition from A to $G$ at position 2756, exon 26 ( $r$ 1805087) causes an amino acid change of Asp to Gly, which has been reported to modify enzyme activity and alter DNA methylation processes [186,187]. However, no significant was found with ORR (OR=0.66; $\mathrm{Cl}_{95 \%}=0.23,1.89$ for $A G / G G$ vs $A A)$ and OS (HR=0.99; $\mathrm{Cl}_{95}=0.23,1.89$ for $A G / G G$ vs $\left.A A\right)$ in two studies including 465 I-IV and $101 \mathrm{IIIB} / \mathrm{IV}$ NSCLC patients treated with platinum based chemotherapy (Table 9) $[56,57]$.

\subsection{SLC19A1}

The reduced folate carrier SLC19A1 is responsible for the transport of folate drugs into the cell, such as pemetrexed, a drug that is usually given in combination with carboplatin/cisplatin [188]. Polymorphisms in this gene may modify the passage of this drug into the tumor cell.

A single nucleotide transition ( $G \rightarrow A$, rs1051266) at exon 2, which induces an $\mathrm{Arg} \rightarrow \mathrm{His}$ replacement in codon 27 , has demonstrated to alter pemetrexed-platinum combination 
efficacy [55]. The GG genotype has been associated with better OS (HR=1.76; $\mathrm{Cl}_{95 \%}=1.11,2.78$ for $A G / A A$ vs GG) in 136 lung cancer patients (Table 9) [55]. However, no significant associations have been reported for ORR, PFS and toxicity (Table 9) $[55,122,189-191]$.

\section{CYTOKINE SIGNALING}

The innate immune cells induce inflammation as a physiological process aimed to combat infection. However, chronic inflammation may cause persistent tissue damage and cellular proliferation leading to metaplasia and dysplasia [192,193]. Consequently, there are prominent connections between chronic inflammation, infection and early stage of neoplastic development. Clinical and epidemiological studies have reported that $20 \%$ of tumors are associated to chronic infection, $30 \%$ associated to tobacco smoking and pollutant inhalation and $35 \%$ are related to nutrition [194].

Growth, differentiation, and activation of immune cells are mediated by a family of cytokines referred as interleukins (ILS) [195]. During tumor development, ILs act as autocrine and paracrine growth factors, inhibiting apoptosis at the site of inflammation [58]. IL polymorphisms have recently been associated with OS in stage IIIB-IV NSCLC patients receiving platinum based chemotherapy. In the case of the IL1B rs1143634 polymorphism, the T-allele has been correlated with better OS ( $\mathrm{HR}=0.78 ; 95 \% \mathrm{Cl}=0.63,0.98$ for $\mathrm{CT} / \mathrm{TT}$ vs $\mathrm{CC}$ ) and PFS ( $\mathrm{HR}=0.73 ; \mathrm{Cl}_{95 \%}=0.57,0.93$ for $\mathrm{CT} / \mathrm{TT}$ vs $\mathrm{CC}$ ) in 651 Caucasian patients [60]. Likewise, the CC genotype for IL6 rs 1800795 was found to be associated with better OS (HR=1.682; $\mathrm{Cl}_{95 \%}=1.077$, 2.628 for CG/GG vs CC) in 414 Portuguese stage I-IV NSCLC patients [59]. Finally, the CT/TT genotypes for IL12A (rs662959) ( $\mathrm{HR}=1.41 ; \mathrm{Cl}_{95 \%}=1.08,1.83$ for CT/TT vS CC), AC/CC for IL13 ( $r$ 1881457) (HR=1.29; $\mathrm{Cl}_{95 \%}=1.00,1.66$ for $\mathrm{AC} / \mathrm{CC}$ vs AA) and GG for IL16 (rs7170924) ( $\mathrm{HR}=0.65 ; \mathrm{Cl}_{95 \%}=0.50,0.83$ for $\mathrm{GT} / \mathrm{TT}$ vs $\mathrm{GG}$ ) have been associated with lower PFS in 651 Caucasian stage I-IV NSCLC patients [60].

\section{CONCLUSIONS}

The influence of gene polymorphisms in the NER pathway on clinical outcome has been extensively investigated in advanced NSCLC patients treated with platinum-based chemotherapy but contradictory results have been reported. The most recent and thorough meta-analyses have failed to show an association between ERCC1 C118T/C8092A and ERCC5 rs 1047768 polymorphisms and response to platinum based chemotherapy. However, other polymorphisms in ERCC2 (Lys751Gln and Asp312Asn) and ERCC5 (rs2094258 and rs2296147) and have been related with OS and PFS, respectively.

The Arg194Trp and GIn399Arg polymorphisms in XRCC1, a protein of the BER pathway, have also been extensively investigated. Their effects seem to be dependent on ethnicity, and recent meta-analyses have confirmed an association with response in Asian but not in Caucasian patients. The influence on ORR of the rs 861539 polymorphism in XRCC3, a protein of the DSB pathway, has also been confirmed in a meta-analysis.

Finally, SNPs in genes coding proteins of the p53, PI3K, TGF- $\beta$, membrane transporters, gluthatione metabolism enzymes and cytokine pathways have been less extensively investigated. Some polymorphisms have been reported to be associated with toxicity or clinical outcome, but data generally come from a limited number of studies and need to be confirmed.

In summary, we suggested that those polymorphisms in genes most extensively studied such as ERCC2, XRCC1 and XRCC3 may be used in the future as a prognostic and predictive biomarkers informing patient care. ERCC1 C118T/C8092A gene polymorphisms may also be used in clinical practice after clarifying the conflicting results that may be based on the heterogeneity of the population. Polymorphisms in genes belonging to TP53, PI3K, TGF- $\beta$ pathways, membrane transporters, gluthatione metabolism enzymes and cytokine pathways 
have showed an influence on clinical outcomes of NSCLC patients treated with platinum-based chemotherapy but the sample size is insufficient to confirm its effect on clinical outcomes of platinum-based chemotherapy. Thus, further examination involving a large homogeneous sample size (stratified by gender, age and smoking status) and longer follow up is required for these polymorphisms.

\section{REFERENCES}

1 Siegel RL, Miller KD, Jemal A. Cancer statistics, 2016. CA: a cancer journal for clinicians 2016;66:7-30.

2 Edge S, Byrd, D.R., Compton, C.C., Fritz, A.G., Greene, F.L., Trotti, A. Ajcc cancer staging manual, 7th ed., 2010.

3 Herbst RS HJ, Lippman SM. Lung cancer. N Engl J Med 2008;359:1367-1380.

4 Molina JR, Yang P, Cassivi SD, Schild SE, Adjei AA. Non-small cell lung cancer: Epidemiology, risk factors, treatment, and survivorship. Mayo Clinic proceedings 2008;83:584594.

5 Zhong C, Liu H, Jiang L, Zhang W, Yao F. Chemotherapy plus best supportive care versus best supportive care in patients with non-small cell lung cancer: A meta-analysis of randomized controlled trials. PloS one 2013;8:e58466.

6 Fossella F, Pereira JR, von Pawel J, Pluzanska A, Gorbounova V, Kaukel E, Mattson KV, Ramlau R, Szczesna A, Fidias P, Millward M, Belani CP. Randomized, multinational, phase iii study of docetaxel plus platinum combinations versus vinorelbine plus cisplatin for advanced non-small-cell lung cancer: The tax 326 study group. Journal of clinical oncology : official journal of the American Society of Clinical Oncology 2003;21:3016-3024.

7 Kelly K, Crowley J, Bunn PA, Jr., Presant CA, Grevstad PK, Moinpour CM, Ramsey SD, Wozniak AJ, Weiss GR, Moore DF, Israel VK, Livingston RB, Gandara DR. Randomized phase iii trial of paclitaxel plus carboplatin versus vinorelbine plus cisplatin in the treatment of patients with advanced non--small-cell lung cancer: A southwest oncology group trial. Journal of clinical oncology : official journal of the American Society of Clinical Oncology 2001;19:3210-3218.

8 Scagliotti GV, De Marinis F, Rinaldi M, Crino L, Gridelli C, Ricci S, Matano E, Boni C, Marangolo M, Failla G, Altavilla G, Adamo V, Ceribelli A, Clerici M, Di Costanzo F, Frontini L, Tonato $\mathrm{M}$. Phase iii randomized trial comparing three platinum-based doublets in advanced non-small-cell lung cancer. Journal of clinical oncology : official journal of the American Society of Clinical Oncology 2002;20:4285-4291.

9 Schiller JH, Harrington D, Belani CP, Langer C, Sandler A, Krook J, Zhu J, Johnson DH. Comparison of four chemotherapy regimens for advanced non-small-cell lung cancer. The New England journal of medicine 2002;346:92-98.

10 Mok TS WY, Thongprasert S, Yang $\mathrm{CH}$, Chu DT, Saijo $\mathrm{N}$, Sunpaweravong $\mathrm{P}$, Han $\mathrm{B}$, Margono B, Ichinose $Y$, Nishiwaki $Y$, Ohe $Y$, Yang JJ, Chewaskulyong B, Jiang $H$, Duffield EL, Watkins CL, Armour AA, Fukuoka M. Gefitinib or carboplatin-paclitaxel in pulmonary adenocarcinoma. N Engl J Med 2009;361:947-957.

11 Wei HB, Lu XS, Shang LH, Xu G, Hu J, Che DH, Liu F, Wu Y, Zhang GM, Yu Y. Polymorphisms of ercc1 c118t/c8092a and mdr1 c3435t predict outcome of platinum-based chemotherapies in advanced non-small cell lung cancer: A meta-analysis. Archives of medical research 2011;42:412-420.

12 Wei SZ, Zhan P, Shi MQ, Shi Y, Qian Q, Yu LK, Song Y. Predictive value of ercc1 and xpd polymorphism in patients with advanced non-small cell lung cancer receiving platinum-based chemotherapy: A systematic review and meta-analysis. Med Oncol 2011;28:315-321. 
13 Yang $Y$, Xian L. The association between the ercc1/2 polymorphisms and the clinical outcomes of the platinum-based chemotherapy in non-small cell lung cancer (nsclc): $A$ systematic review and meta-analysis. Tumour biology : the journal of the International Society for Oncodevelopmental Biology and Medicine 2014;35:2905-2921.

14 Huang SJ, Wang YF, Jin ZY, Sun JY, Guo ZL. Role of ercc1 variants in response to chemotherapy and clinical outcome of advanced non-small cell lung cancer. Tumour biology : the journal of the International Society for Oncodevelopmental Biology and Medicine 2014;35:4023-4029.

15 Li L, Wan C, Wen FQ. Polymorphisms in the xrcc1 gene are associated with treatment response to platinum chemotherapy in advanced non-small cell lung cancer patients based on meta-analysis. Genetics and molecular research : GMR 2014;13:3772-3786.

16 Shen XY, Lu FZ, Wu Y, Zhao LT, Lin ZF. Xrcc3 thr241met polymorphism and clinical outcomes of nsclc patients receiving platinum-based chemotherapy: A systematic review and meta-analysis. PloS one 2013;8:e69553.

17 Zhu N, Gong Y, He J, Xia J, Chen X. Influence of methylenetetrahydrofolate reductase c677t polymorphism on the risk of lung cancer and the clinical response to platinum-based chemotherapy for advanced non-small cell lung cancer: An updated meta-analysis. Yonsei medical journal 2013;54:1384-1393.

18 Kartalou M, Essigmann JM. Recognition of cisplatin adducts by cellular proteins. Mutation research 2001;478:1-21.

19 Jordan P, Carmo-Fonseca M. Molecular mechanisms involved in cisplatin cytotoxicity. Cell Mol Life Sci 2000;57:1229-1235.

20 Sancar A. DNA repair in humans. Annu Rev Genet 1995;29:69-105.

21 Garcia-Campelo R, Alonso-Curbera G, Anton Aparicio LM, Rosell R. Pharmacogenomics in lung cancer: An analysis of DNA repair gene expression in patients treated with platinumbased chemotherapy. Expert Opin Pharmacother 2005;6:2015-2026.

22 Jin S, Levine AJ. The p53 functional circuit. Journal of cell science 2001;114:4139-4140.

23 Michael D, Oren M. The p53-mdm2 module and the ubiquitin system. Semin Cancer Biol 2003;13:49-58.

24 Shiraishi K, Kohno T, Tanai C, Goto Y, Kuchiba A, Yamamoto S, Tsuta K, Nokihara H, Yamamoto N, Sekine I, Ohe Y, Tamura T, Yokota J, Kunitoh H. Association of DNA repair gene polymorphisms with response to platinum-based doublet chemotherapy in patients with nonsmall-cell lung cancer. Journal of clinical oncology : official journal of the American Society of Clinical Oncology 2010;28:4945-4952.

25 Zheng D, Chen Y, Gao C, Wei Y, Cao G, Lu N, Hou Y, Jiang X, Wang J. Polymorphisms of p53 and $m d m 2$ genes are associated with severe toxicities in patients with non-small cell lung cancer. Cancer biology \& therapy 2014;15:1542-1551.

26 Dong J, Ren B, Hu Z, Chen J, Hu L, Dai J, Jin G, Xu L, Shen H. Mdm2 snp309 contributes to non-small cell lung cancer survival in chinese. Molecular carcinogenesis 2011;50:433-438.

27 Qian J, Liu H, Gu S, Wu Q, Zhao X, Wu W, Wang H, Wang J, Chen H, Zhang W, Wei Q, Jin L, Lu D. Genetic variants of the $\mathrm{mdm} 2$ gene are predictive of treatment-related toxicities and overall survival in patients with advanced nsclc. Clinical lung cancer 2015;16:e37-53.

$28 \mathrm{Pu} X$, Hildebrandt MA, Lu C, Lin J, Stewart DJ, Ye Y, Gu J, Spitz MR, Wu X. $\mathrm{Pi} 3 \mathrm{k} / \mathrm{pten} / \mathrm{akt} / \mathrm{mtor}$ pathway genetic variation predicts toxicity and distant progression in lung cancer patients receiving platinum-based chemotherapy. Lung cancer 2011;71:82-88. 
29 Lin M, Stewart DJ, Spitz MR, Hildebrandt MA, Lu C, Lin J, Gu J, Huang M, Lippman SM, $\mathrm{Wu} \mathrm{X}$. Genetic variations in the transforming growth factor-beta pathway as predictors of survival in advanced non-small cell lung cancer. Carcinogenesis 2011;32:1050-1056.

30 Manning BD, Cantley LC. Akt/pkb signaling: Navigating downstream. Cell 2007;129:1261-1274.

31 Nicholson KM, Anderson NG. The protein kinase b/akt signalling pathway in human malignancy. Cell Signal 2002;14:381-395.

32 Ikushima $\mathrm{H}$, Miyazono K. Tgfbeta signalling: A complex web in cancer progression. Nature reviews Cancer 2010;10:415-424.

33 Yin JY, Huang Q, Zhao YC, Zhou HH, Liu ZQ. Meta-analysis on pharmacogenetics of platinum-based chemotherapy in non small cell lung cancer (nsclc) patients. PloS one 2012;7:e38150.

34 Weissfeld JL, Diergaarde B, Nukui T, Buch S, Pennathur A, Socinski MA, Siegfried JM, Romkes $\mathrm{M}$. Inherited variation in the atp-binding cassette transporter abcb1 and survival after chemotherapy for stage iii-iv lung cancer. J Thorac Oncol 2014;9:1264-1271.

35 Lamba JK, Fridley BL, Ghosh TM, Yu Q, Mehta G, Gupta P. Genetic variation in platinating agent and taxane pathway genes as predictors of outcome and toxicity in advanced non-small-cell lung cancer. Pharmacogenomics 2014;15:1565-1574.

36 Thiebaut F, Tsuruo T, Hamada H, Gottesman MM, Pastan I, Willingham MC. Cellular localization of the multidrug-resistance gene product p-glycoprotein in normal human tissues. Proc Natl Acad Sci U S A 1987;84:7735-7738.

37 Ambudkar SV, Dey S, Hrycyna CA, Ramachandra M, Pastan I, Gottesman MM. Biochemical, cellular, and pharmacological aspects of the multidrug transporter. Annual review of pharmacology and toxicology 1999;39:361-398.

38 Borst P, Elferink RO. Mammalian abc transporters in health and disease. Annual review of biochemistry 2002;71:537-592.

39 Jones PM, George AM. The abc transporter structure and mechanism: Perspectives on recent research. Cell Mol Life Sci 2004;61:682-699.

40 Sakaeda T, Nakamura T, Okumura K. Mdr1 genotype-related pharmacokinetics and pharmacodynamics. Biol Pharm Bull 2002;25:1391-1400.

41 Takara K, Sakaeda T, Okumura K. An update on overcoming mdr1-mediated multidrug resistance in cancer chemotherapy. Curr Pharm Des 2006;12:273-286.

42 Deng JH, Deng J, Shi DH, Ouyang XN, Niu PG. Clinical outcome of cisplatin-based chemotherapy is associated with the polymorphisms of gstp1 and $\operatorname{xrcc1}$ in advanced non-small cell lung cancer patients. Clinical \& translational oncology : official publication of the Federation of Spanish Oncology Societies and of the National Cancer Institute of Mexico 2015; 17:720-726.

43 Han B, Guo Z, Ma Y, Kang S, Wang Y, Wei Q, Wu X. Association of gstp1 and xrcc1 gene polymorphisms with clinical outcome of advanced non-small cell lung cancer patients with cisplatin-based chemotherapy. International journal of clinical and experimental pathology 2015;8:4113-4119.

$44 \quad$ Lv H, Han T, Shi X, Yao Y, Yao Y, Qiu W, Yue L, Liang J. Genetic polymorphism of gstp1 and ercc1 correlated with response to platinum-based chemotherapy in non-small cell lung cancer. Med Oncol 2014;31:86. 
45 Sun N, Sun X, Chen B, Cheng H, Feng J, Cheng L, Lu Z. Mrp2 and gstp1 polymorphisms and chemotherapy response in advanced non-small cell lung cancer. Cancer chemotherapy and pharmacology 2010;65:437-446.

46 Wu G, Jiang B, Liu X, Shen Y, Yang S. Association of gsts gene polymorphisms with treatment outcome of advanced non-small cell lung cancer patients with cisplatin-based chemotherapy. International journal of clinical and experimental pathology 2015;8:1334613352.

47 Zhou F, Yu Z, Jiang T, Lv H, Yao R, Liang J. Genetic polymorphisms of gstp1 and xrcc1: Prediction of clinical outcome of platinum-based chemotherapy in advanced non-small cell lung cancer (nsclc) patients. Swiss medical weekly 2011;141:w13275.

48 Booton R, Ward T, Heighway J, Ashcroft L, Morris J, Thatcher N. Glutathione-stransferase $\mathrm{p} 1$ isoenzyme polymorphisms, platinum-based chemotherapy, and non-small cell lung cancer. J Thorac Oncol 2006;1:679-683.

49 Joerger M, Burgers SA, Baas P, Smit EF, Haitjema TJ, Bard MP, Doodeman VD, Smits PH, Vincent $A$, Huitema AD, Beijnen JH, Schellens JH. Germline polymorphisms in patients with advanced nonsmall cell lung cancer receiving first-line platinum-gemcitabine chemotherapy: $A$ prospective clinical study. Cancer 2012;118:2466-2475.

50 Li YN, Gulati S, Baker PJ, Brody LC, Banerjee R, Kruger WD. Cloning, mapping and rna analysis of the human methionine synthase gene. Hum Mol Genet 1996;5:1851-1858.

51 Goyette P, Sumner JS, Milos R, Duncan AM, Rosenblatt DS, Matthews RG, Rozen R. Human methylenetetrahydrofolate reductase: Isolation of cdna, mapping and mutation identification. Nature genetics 1994;7:195-200.

52 Chu J, Dolnick BJ. Natural antisense (rtsalpha) rna induces site-specific cleavage of thymidylate synthase mrna. Biochimica et biophysica acta 2002;1587:183-193.

53 Hum DW, Bell AW, Rozen R, Mackenzie RE. Primary structure of a human trifunctional enzyme. Isolation of a cdna encoding methylenetetrahydrofolate dehydrogenasemethenyltetrahydrofolate cyclohydrolase-formyltetrahydrofolate synthetase. The Journal of biological chemistry 1988;263:15946-15950.

54 Chiao JH, Roy K, Tolner B, Yang CH, Sirotnak FM. Rfc-1 gene expression regulates folate absorption in mouse small intestine. The Journal of biological chemistry 1997;272:1116511170.

55 Corrigan A, Walker JL, Wickramasinghe S, Hernandez MA, Newhouse SJ, Folarin AA, Lewis CM, Sanderson JD, Spicer J, Marinaki AM. Pharmacogenetics of pemetrexed combination therapy in lung cancer: Pathway analysis reveals novel toxicity associations. The pharmacogenomics journal 2014;14:411-417.

56 Cui LH YZ, Zhang TT, Shin MH, Kim HN, Choi JS. Influence of polymorphisms in mthfr $677 \mathrm{c} \rightarrow \mathrm{t}$, tyms $3 \mathrm{r} \rightarrow 2 \mathrm{r}$ and $\mathrm{mtr} 2756 \mathrm{a} \rightarrow \mathrm{g}$ on nsclc risk and response to platinum-based chemotherapy in advanced nsclc. Pharmacogenomics 2011;12:797-808.

57 Matakidou A, El Galta R, Rudd MF, Webb EL, Bridle H, Eisen T, Houlston RS. Prognostic significance of folate metabolism polymorphisms for lung cancer. British journal of cancer 2007; 97:247-252.

58 Pollard JW. Tumour-educated macrophages promote tumour progression and metastasis. Nat Rev Cancer 2004;4:71-78. 
59 Gomes M, Coelho A, Araujo A, Azevedo A, Teixeira AL, Catarino R, Medeiros R. II-6 polymorphism in non-small cell lung cancer: A prognostic value? Tumour biology : the journal of the International Society for Oncodevelopmental Biology and Medicine 2015

60 Woods NT, Monteiro AN, Thompson ZJ, Amankwah EK, Naas N, Haura EB, Beg AA, Schabath MB. Interleukin polymorphisms associated with overall survival, disease-free survival, and recurrence in non-small cell lung cancer patients. Molecular carcinogenesis 2015

61 Topping RP, Wilkinson JC, Scarpinato KD. Mismatch repair protein deficiency compromises cisplatin-induced apoptotic signaling. The Journal of biological chemistry 2009;284:14029-14039.

62 Akyuz N, Boehden GS, Susse S, Rimek A, Preuss U, Scheidtmann KH, Wiesmuller L. DNA substrate dependence of p53-mediated regulation of double-strand break repair. Molecular and cellular biology 2002;22:6306-6317.

63 Offer H, Zurer I, Banfalvi G, Reha'k M, Falcovitz A, Milyavsky M, Goldfinger N, Rotter V. P53 modulates base excision repair activity in a cell cycle-specific manner after genotoxic stress. Cancer research 2001;61:88-96.

64 Yamane K, Katayama E, Tsuruo T. P53 contains a DNA break-binding motif similar to the functional part of brct-related region of rb. Oncogene 2001;20:2859-2867.

65 Zhu Q, Wani MA, El-Mahdy M, Wani AA. Decreased DNA repair efficiency by loss or disruption of p53 function preferentially affects removal of cyclobutane pyrimidine dimers from non-transcribed strand and slow repair sites in transcribed strand. The Journal of biological chemistry 2000;275:11492-11497.

66 de Laat WL, Appeldoorn E, Jaspers NG, Hoeijmakers JH. DNA structural elements required for ercc1-xpf endonuclease activity. The Journal of biological chemistry 1998;273:7835-7842.

67 Coin F, Marinoni JC, Rodolfo C, Fribourg S, Pedrini AM, Egly JM. Mutations in the xpd helicase gene result in xp and ttd phenotypes, preventing interaction between xpd and the p44 subunit of tfiih. Nature genetics 1998;20:184-188.

68 Sijbers AM, de Laat WL, Ariza RR, Biggerstaff M, Wei YF, Moggs JG, Carter KC, Shell BK, Evans $E$, de Jong MC, Rademakers S, de Rooij J, Jaspers NG, Hoeijmakers JH, Wood RD. Xeroderma pigmentosum group $f$ caused by a defect in a structure-specific DNA repair endonuclease. Cell 1996;86:811-822.

69 Su D, Ma S, Liu P, Jiang Z, Lv W, Zhang Y, Deng Q, Smith S, Yu H. Genetic polymorphisms and treatment response in advanced non-small cell lung cancer. Lung cancer 2007;56:281-288.

70 Cheng J, Ha M, Wang Y, Sun J, Chen J, Wang Y, Tong C. A c118t polymorphism of ercc1 and response to cisplatin chemotherapy in patients with late-stage non-small cell lung cancer. Journal of cancer research and clinical oncology 2012;138:231-238.

71 Wang J, Zhang $\mathrm{Q}$, Zhang $\mathrm{H}$, Wang $\mathrm{Q}$, Yang $\mathrm{X}, \mathrm{Gu} \mathrm{Y}$, Zhang S. [association between polymorphisms of ercc1 and response in patients with advanced non-small cell lung cancer receiving cisplatin-based chemotherapy]. Zhongguo fei ai za zhi $=$ Chinese journal of lung cancer 2010;13:337-341.

72 Gao H, Ge RC, Liu HY, Wang Y, Yan S. Effect of ercc1 polymorphism on the response to chemotherapy and clinical outcome of non-small cell lung cancer. Genetics and molecular research : GMR 2014;13:8997-9004. 
73 Li F, Sun X, Sun N, Qin S, Cheng H, Feng J, Chen B, Cheng L, Lu Z, Ji J, Zhou Y. Association between polymorphisms of ercc1 and $\mathrm{xpd}$ and clinical response to platinum-based chemotherapy in advanced non-small cell lung cancer. Am J Clin Oncol 2010;33:489-494.

74 Du Y, Su T, Zhao L, Tan X, Chang W, Zhang H, Cao G. Associations of polymorphisms in DNA repair genes and mdr1 gene with chemotherapy response and survival of non-small cell lung cancer. PloS one 2014;9:e99843.

75 Shi ZH, Shi GY, Liu LG. Polymorphisms in ercc1 and xpf gene and response to chemotherapy and overall survival of non-small cell lung cancer. International journal of clinical and experimental pathology 2015;8:3132-3137.

76 Sullivan I, Salazar J, Majem M, Pallares C, Del Rio E, Paez D, Baiget M, Barnadas A. Pharmacogenetics of the DNA repair pathways in advanced non-small cell lung cancer patients treated with platinum-based chemotherapy. Cancer letters 2014;353:160-166.

77 Zhao X, Zhang Z, Yuan Y, Yuan X. Polymorphisms in ercc1 gene could predict clinical outcome of platinum-based chemotherapy for non-small cell lung cancer patients. Tumour biology : the journal of the International Society for Oncodevelopmental Biology and Medicine 2014;35:8335-8341.

78 Dong J, Hu Z, Shu Y, Pan S, Chen W, Wang Y, Hu L, Jiang Y, Dai J, Ma H, Jin G, Shen H. Potentially functional polymorphisms in DNA repair genes and non-small-cell lung cancer survival: A pathway-based analysis. Molecular carcinogenesis 2012;51:546-552.

79 Isla D, Sarries C, Rosell R, Alonso G, Domine M, Taron M, Lopez-Vivanco G, Camps C, Botia M, Nunez L, Sanchez-Ronco M, Sanchez JJ, Lopez-Brea M, Barneto I, Paredes A, Medina $B$, Artal A, Lianes P. Single nucleotide polymorphisms and outcome in docetaxel-cisplatintreated advanced non-small-cell lung cancer. Annals of oncology : official journal of the European Society for Medical Oncology / ESMO 2004;15:1194-1203.

80 Okuda K, Sasaki H, Hikosaka Y, Kawano O, Yukiue H, Yano M, Fujii Y. Excision repair cross complementation group 1 polymorphisms predict overall survival after platinum-based chemotherapy for completely resected non-small-cell lung cancer. The Journal of surgical research 2011;168:206-212.

81 Park SY, Hong YC, Kim JH, Kwak SM, Cho JH, Lee HL, Ryu JS. Effect of ercc1 polymorphisms and the modification by smoking on the survival of non-small cell lung cancer patients. Med Oncol 2006;23:489-498.

82 Ryu JS, Hong YC, Han HS, Lee JE, Kim S, Park YM, Kim YC, Hwang TS. Association between polymorphisms of ercc1 and xpd and survival in non-small-cell lung cancer patients treated with cisplatin combination chemotherapy. Lung cancer 2004;44:311-316.

83 Zhou C, Ren S, Zhou S, Zhang L, Su C, Zhang Z, Deng Q, Zhang J. Predictive effects of ercc1 and xrcc3 snp on efficacy of platinum-based chemotherapy in advanced nsclc patients. Japanese journal of clinical oncology 2010;40:954-960.

84 Ren S, Zhou S, Wu F, Zhang L, Li X, Zhang J, Xu J, Lv M, Zhang J, Zhou C. Association between polymorphisms of DNA repair genes and survival of advanced nsclc patients treated with platinum-based chemotherapy. Lung cancer 2012;75:102-109.

85 Takenaka T, Yano T, Kiyohara C, Miura N, Kouso H, Ohba T, Kometani T, Shoji F, Yoshino I, Maehara Y. Effects of excision repair cross-complementation group 1 (ercc1) single nucleotide polymorphisms on the prognosis of non-small cell lung cancer patients. Lung cancer 2010;67:101-107.

86 Zhou W, Gurubhagavatula S, Liu G, Park S, Neuberg DS, Wain JC, Lynch TJ, Su L, Christiani DC. Excision repair cross-complementation group 1 polymorphism predicts overall 
survival in advanced non-small cell lung cancer patients treated with platinum-based chemotherapy. Clinical cancer research : an official journal of the American Association for Cancer Research 2004;10:4939-4943.

87 Kalikaki A, Kanaki M, Vassalou H, Souglakos J, Voutsina A, Georgoulias V, Mavroudis D. DNA repair gene polymorphisms predict favorable clinical outcome in advanced non-small-cell lung cancer. Clinical lung cancer 2009;10:118-123.

88 Kalikaki A, Voutsina A, Koutsopoulos A, Papadaki C, Sfakianaki M, Yachnakis E, Xyrafas A, Kotsakis A, Agelaki S, Souglakos J, Mavroudis D, Georgoulias V. Ercc1 snps as potential predictive biomarkers in non-small cell lung cancer patients treated with platinum-based chemotherapy. Cancer investigation 2015;33:107-113.

89 Olaussen KA, Dunant A, Fouret $P$, Brambilla E, Andre F, Haddad V, Taranchon E, Filipits M, Pirker R, Popper HH, Stahel R, Sabatier L, Pignon JP, Tursz T, Le Chevalier T, Soria JC. DNA repair by ercc1 in non-small-cell lung cancer and cisplatin-based adjuvant chemotherapy. The New England journal of medicine 2006;355:983-991.

90 Park DJ, Zhang W, Stoehlmacher J, Tsao-Wei D, Groshen S, Gil J, Yun J, Sones E, Mallik $\mathrm{N}$, Lenz $\mathrm{HJ}$. Ercc1 gene polymorphism as a predictor for clinical outcome in advanced colorectal cancer patients treated with platinum-based chemotherapy. Clin Adv Hematol Oncol 2003;1:162-166.

91 Tibaldi C, Giovannetti E, Vasile E, Mey V, Laan AC, Nannizzi S, Di Marsico R, Antonuzzo A, Orlandini C, Ricciardi S, Del Tacca M, Peters GJ, Falcone A, Danesi R. Correlation of cda, ercc1, and xpd polymorphisms with response and survival in gemcitabine/cisplatin-treated advanced non-small cell lung cancer patients. Clinical cancer research : an official journal of the American Association for Cancer Research 2008;14:1797-1803.

92 de las Penas R, Sanchez-Ronco M, Alberola V, Taron M, Camps C, Garcia-Carbonero R, Massuti B, Queralt C, Botia M, Garcia-Gomez R, Isla D, Cobo M, Santarpia M, Cecere F, Mendez $P$, Sanchez JJ, Rosell R. Polymorphisms in DNA repair genes modulate survival in cisplatin/gemcitabine-treated non-small-cell lung cancer patients. Annals of oncology : official journal of the European Society for Medical Oncology / ESMO 2006;17:668-675.

93 Mathiaux J, Le Morvan V, Pulido M, Jougon J, Begueret $H$, Robert J. Role of DNA repair gene polymorphisms in the efficiency of platinum-based adjuvant chemotherapy for non-small cell lung cancer. Molecular diagnosis \& therapy 2011;15:159-166.

94 Hong W, Wang K, Zhang YP, Kou JY, Hong D, Su D, Mao WM, Yu XM, Xie FJ, Wang XJ. Methylenetetrahydrofolate reductase $\mathrm{c} 677 \mathrm{t}$ polymorphism predicts response and time to progression to gemcitabine-based chemotherapy for advanced non-small cell lung cancer in a chinese han population. Journal of Zhejiang University Science B 2013;14:207-215.

95 Krawczyk P, Kucharczyk T, Kowalski DM, Powrozek T, Ramlau R, Kalinka-Warzocha E, Winiarczyk K, Knetki-Wroblewska M, Wojas-Krawczyk K, Kalakucka K, Dyszkiewicz W, Krzakowski M, Milanowski J. Polymorphisms in ts, mthfr and ercc1 genes as predictive markers in first-line platinum and pemetrexed therapy in nsclc patients. Journal of cancer research and clinical oncology 2014;140:2047-2057.

96 Krawczyk P, Wojas-Krawczyk K, Mlak R, Kucharczyk T, Biernacka B, Milanowski J. Predictive value of ercc1 single-nucleotide polymorphism in patients receiving platinum-based chemotherapy for locally-advanced and advanced non-small cell lung cancer--a pilot study. Folia histochemica et cytobiologica / Polish Academy of Sciences, Polish Histochemical and Cytochemical Society 2012;50:80-86.

97 Li D, Zhou Q, Liu Y, Yang Y, Li Q. DNA repair gene polymorphism associated with sensitivity of lung cancer to therapy. Med Oncol 2012;29:1622-1628. 
98 Liao WY, Shih JY, Chang GC, Cheng YK, Yang JC, Chen YM, Yu CJ. Genetic polymorphism of $\operatorname{xrcc1}$ arg399gIn is associated with survival in non-small-cell lung cancer patients treated with gemcitabine/platinum. J Thorac Oncol 2012;7:973-981.

99 Tiseo M, Bordi P, Bortesi B, Boni L, Boni C, Baldini E, Grossi F, Recchia F, Zanelli F, Fontanini G, Naldi N, Campanini N, Azzoni C, Bordi C, Ardizzoni A. Ercc1/brca1 expression and gene polymorphisms as prognostic and predictive factors in advanced nsclc treated with or without cisplatin. British journal of cancer 2013;108:1695-1703.

100 Zhang $Z Y$, Tian $X$, Wu R, Liang $Y$, Jin XY. Predictive role of ercc1 and xpd genetic polymorphisms in survival of chinese non-small cell lung cancer patients receiving chemotherapy. Asian Pacific journal of cancer prevention : APJCP 2012;13:2583-2586.

101 Wei HB, Hu J, Shang LH, Zhang YY, Lu FF, Wei M, Yu Y. A meta-analytic review of ercc1/mdr1 polymorphism and chemosensitivity to platinum in patients with advanced nonsmall cell lung cancer. Chinese medical journal 2012;125:2902-2907.

102 Huang D, Zhou Y. Nucleotide excision repair gene polymorphisms and prognosis of non-small cell lung cancer patients receiving platinum-based chemotherapy: A meta-analysis based on 44 studies. Biomedical reports 2014;2:452-462.

103 Chen S, Huo X, Lin Y, Ban H, Lin Y, Li W, Zhang B, Au WW, Xu X. Association of mdr1 and ercc1 polymorphisms with response and toxicity to cisplatin-based chemotherapy in nonsmall-cell lung cancer patients. International journal of hygiene and environmental health 2010;213:140-145.

104 Gandara DR, Kawaguchi T, Crowley J, Moon J, Furuse K, Kawahara M, Teramukai S, Ohe Y, Kubota K, Williamson SK, Gautschi O, Lenz HJ, McLeod HL, Lara PN, Jr., Coltman CA, Jr., Fukuoka M, Saijo N, Fukushima M, Mack PC. Japanese-us common-arm analysis of paclitaxel plus carboplatin in advanced non-small-cell lung cancer: A model for assessing populationrelated pharmacogenomics. Journal of clinical oncology : official journal of the American Society of Clinical Oncology 2009;27:3540-3546.

105 Ludovini V, Floriani I, Pistola L, Minotti V, Meacci M, Chiari R, Garavaglia D, Tofanetti FR, Flacco A, Siggillino A, Baldelli E, Tonato M, Crino L. Association of cytidine deaminase and xeroderma pigmentosum group $\mathrm{d}$ polymorphisms with response, toxicity, and survival in cisplatin/gemcitabine-treated advanced non-small cell lung cancer patients. J Thorac Oncol 2011;6:2018-2026.

106 Metro G, Chiari R, Mare M, Giannarelli D, Tofanetti FR, Minotti V, Ferraldeschi M, Giuffrida D, Marcomigni L, Bennati C, Fischer MJ, Meacci M, Bellavita R, Pistola L, Ludovini V, Crino L. Carboplatin plus pemetrexed for platinum-pretreated, advanced non-small cell lung cancer: A retrospective study with pharmacogenetic evaluation. Cancer chemotherapy and pharmacology 2011;68:1405-1412.

107 Powrozek T, Mlak R, Krawczyk P, Homa I, Ciesielka M, Koziol P, Prendecka M, Milanowski J, Malecka-Massalska T. The relationship between polymorphisms of genes regulating DNA repair or cell division and the toxicity of platinum and vinorelbine chemotherapy in advanced nsclc patients. Clinical \& translational oncology : official publication of the Federation of Spanish Oncology Societies and of the National Cancer Institute of Mexico 2015

108 Suk R, Gurubhagavatula S, Park S, Zhou W, Su L, Lynch TJ, Wain JC, Neuberg D, Liu G, Christiani DC. Polymorphisms in ercc1 and grade 3 or 4 toxicity in non-small cell lung cancer patients. Clinical cancer research : an official journal of the American Association for Cancer Research 2005;11:1534-1538. 
109 Vinolas N, Provencio M, Reguart N, Cardenal F, Alberola V, Sanchez-Torres JM, Baron FJ, Cobo M, Maestu I, Moreno I, Mesia C, Izquierdo A, Felip E, Lopez-Brea M, Marquez A, Sanchez-Ronco M, Taron M, Santarpia MC, Rosell R. Single nucleotide polymorphisms in mdr1 gen correlates with outcome in advanced non-small-cell lung cancer patients treated with cisplatin plus vinorelbine. Lung cancer 2011;71:191-198.

110 Iranzo V, Sirera R, Bremnes RM, Blasco A, Jantus-Lewintre E, Taron M, Berrocal A, Blasco S, Caballero C, Del Pozo N, Rosell R, Camps C. Chemotherapy-induced neutropenia does not correlate with DNA repair gene polymorphisms and treatment efficacy in advanced nonsmall-cell lung cancer patients. Clinical lung cancer 2011;12:224-230.

111 KimCurran V, Zhou C, Schmid-Bindert G, Shengxiang R, Zhou S, Zhang L, Zhang J. Lack of correlation between ercc1 (c8092a) single nucleotide polymorphism and efficacy/toxicity of platinum based chemotherapy in chinese patients with advanced non-small cell lung cancer. Adv Med Sci 2011;56:30-38.

112 Duell EJ, Wiencke JK, Cheng TJ, Varkonyi A, Zuo ZF, Ashok TD, Mark EJ, Wain JC, Christiani DC, Kelsey KT. Polymorphisms in the DNA repair genes $\operatorname{xrcc1}$ and ercc2 and biomarkers of DNA damage in human blood mononuclear cells. Carcinogenesis 2000;21:965971.

113 Lunn RM, Helzlsouer KJ, Parshad R, Umbach DM, Harris EL, Sanford KK, Bell DA. Xpd polymorphisms: Effects on DNA repair proficiency. Carcinogenesis 2000;21:551-555.

114 Booton R, Ward T, Heighway J, Taylor P, Power F, Ashcroft L, Morris J, Thatcher N. Xeroderma pigmentosum group $d$ haplotype predicts for response, survival, and toxicity after platinum-based chemotherapy in advanced nonsmall cell lung cancer. Cancer 2006;106:24212427.

115 Camps C, Sarries C, Roig B, Sanchez JJ, Queralt C, Sancho E, Martinez N, Taron M, Rosell R. Assessment of nucleotide excision repair xpd polymorphisms in the peripheral blood of gemcitabine/cisplatin-treated advanced non-small-cell lung cancer patients. Clinical lung cancer 2003;4:237-241.

116 Li XD, Han JC, Zhang YJ, Li HB, Wu XY. Common variations of DNA repair genes are associated with response to platinum-based chemotherapy in nsclcs. Asian Pacific journal of cancer prevention : APJCP 2013;14:145-148.

117 Provencio M, Camps C, Cobo M, De las Penas R, Massuti B, Blanco R, Alberola V, Jimenez U, Delgado JR, Cardenal F, Taron M, Ramirez JL, Sanchez A, Rosell R. Prospective assessment of $x r c c 3, x p d$ and aurora kinase a single-nucleotide polymorphisms in advanced lung cancer. Cancer chemotherapy and pharmacology 2012;70:883-890.

118 Wu W, Li H, Wang H, Zhao X, Gao Z, Qiao R, Zhang W, Qian J, Wang J, Chen H, Wei Q, Han B, Lu D. Effect of polymorphisms in xpd on clinical outcomes of platinum-based chemotherapy for chinese non-small cell lung cancer patients. PloS one 2012;7:e33200.

119 Zhang L, Ma W, Li Y, Wu J, Shi GY. Pharmacogenetics of DNA repair gene polymorphisms in non-small-cell lung carcinoma patients on platinum-based chemotherapy. Genetics and molecular research : GMR 2014;13:228-236.

120 Zhou M, Ding YJ, Feng Y, Zhang QR, Xiang Y, Wan HY. Association of xeroderma pigmentosum group $d$ (asp312asn, lys751gln) and cytidine deaminase (lys27gln, ala70thr) polymorphisms with outcome in chinese non-small cell lung cancer patients treated with cisplatin-gemcitabine. Genetics and molecular research : GMR 2014;13:3310-3318.

121 Giachino DF, Ghio P, Regazzoni S, Mandrile G, Novello S, Selvaggi G, Gregori D, DeMarchi M, Scagliotti GV. Prospective assessment of xpd lys751gln and xrcc1 arg399gln single 
nucleotide polymorphisms in lung cancer. Clinical cancer research : an official journal of the American Association for Cancer Research 2007;13:2876-2881.

122 Tiseo M, Giovannetti E, Tibaldi C, Camerini A, Di Costanzo F, Barbieri F, Burgers JA, Vincent A, Peters GJ, Smit EF, Ardizzoni A. Pharmacogenetic study of patients with advanced non-small cell lung cancer (nsclc) treated with second-line pemetrexed or pemetrexedcarboplatin. Lung cancer 2012;78:92-99.

123 Yao CY, Huang XE, Li C, Shen HB, Shi MQ, Feng JF, Pan LX, Tang JH. Lack of influence of xrcc1 and xpd gene polymorphisms on outcome of platinum-based chemotherapy for advanced non small cell lung cancers. Asian Pacific journal of cancer prevention : APJCP 2009;10:859-864.

124 Cheng H, Qin Q, Sun X, Li F, Sun N, Cheng L, Lu Z, Chen B. Predictive effect of xpa and xpd polymorphisms on survival of advanced nsclc patients treated with platinum-based chemotherapy: A three-dimensional (3-d), polyacrylamide gel-based DNA microarray method. Technology in cancer research \& treatment 2013;12:473-482.

125 Liu L, Yuan P, Wu C, Zhang X, Wang F, Guo H, Zhong R, Xu Y, Wu J, Yu D, Wu T, Zhang X, Nie $S$, Miao $X$, Lin D. Assessment of xpd lys751gIn and xrcc1 t-77c polymorphisms in advanced non-small-cell lung cancer patients treated with platinum-based chemotherapy. Lung cancer 2011;73:110-115.

126 Li Y, Huang XE, Jin GF, Shen HB, Xu L. Lack of any relationship between chemotherapy toxicity in non-small cell lung cancer cases and polymorphisms in xrcc1 codon 399 or xpd codon 751. Asian Pacific journal of cancer prevention : APJCP 2011;12:739-742.

127 Kim SH, Lee GW, Lee MJ, Cho YJ, Jeong YY, Kim HC, Lee JD, Hwang YS, Kim IS, Lee S, Oh SY. Clinical significance of ercc2 haplotype-tagging single nucleotide polymorphisms in patients with unresectable non-small cell lung cancer treated with first-line platinum-based chemotherapy. Lung cancer 2012;77:578-584.

128 O'Donovan A, Davies AA, Moggs JG, West SC, Wood RD. Xpg endonuclease makes the $3^{\prime}$ incision in human DNA nucleotide excision repair. Nature 1994;371:432-435.

129 Liu D, Wu J, Shi GY, Zhou HF, Yu Y. Role of xrcc1 and ercc5 polymorphisms on clinical outcomes in advanced non-small cell lung cancer. Genetics and molecular research : GMR 2014;13:3100-3107.

130 Zhang L, Gao G, Li X, Ren S, Li A, Xu J, Zhang J, Zhou C. Association between single nucleotide polymorphisms (snps) and toxicity of advanced non-small-cell lung cancer patients treated with chemotherapy. PloS one 2012;7:e48350.

131 Hu W, Pan J, Zhao P, Yang G, Yang S. Genetic polymorphisms in xpg could predict clinical outcome of platinum-based chemotherapy for advanced non-small cell lung cancer. Tumour biology : the journal of the International Society for Oncodevelopmental Biology and Medicine 2014;35:5561-5567.

132 Sun X, Li F, Sun N, Shukui Q, Baoan C, Jifeng F, Lu C, Zuhong L, Hongyan C, YuanDong C, Jiazhong J, Yingfeng Z. Polymorphisms in xrcc1 and xpg and response to platinum-based chemotherapy in advanced non-small cell lung cancer patients. Lung cancer 2009;65:230-236.

133 Yuli Y, Zhe S, Xia W, Siqing L, Zhenxuan W, Yu-Hua Z, Bing S, Jun-Wei C. Xpg is a novel biomarker of clinical outcome in advanced non-small-cell lung cancer. Pakistan journal of medical sciences 2013;29:762-767.

134 Zharkov DO. Base excision DNA repair. Cell Mol Life Sci 2008;65:1544-1565. 
135 Liu Y, Prasad R, Beard WA, Kedar PS, Hou EW, Shock DD, Wilson SH. Coordination of steps in single-nucleotide base excision repair mediated by apurinic/apyrimidinic endonuclease 1 and DNA polymerase beta. The Journal of biological chemistry 2007;282:13532-13541.

136 Masson M, Niedergang C, Schreiber V, Muller S, Menissier-de Murcia J, de Murcia G. Xrcc1 is specifically associated with poly(adp-ribose) polymerase and negatively regulates its activity following DNA damage. Molecular and cellular biology 1998;18:3563-3571.

137 Whitehouse CJ, Taylor RM, Thistlethwaite A, Zhang H, Karimi-Busheri F, Lasko DD, Weinfeld $\mathrm{M}$, Caldecott KW. Xrcc1 stimulates human polynucleotide kinase activity at damaged DNA termini and accelerates DNA single-strand break repair. Cell 2001;104:107-117.

138 Hong $\mathrm{CY}, \mathrm{Xu} \mathrm{Q}$, Yue $\mathrm{Z}$, Zhang $\mathrm{Y}$, Yuan $\mathrm{Y}$. [correlation of the sensitivity of $\mathrm{np}$ chemotherapy in non-small lung cancer with DNA repair gene xrcc1 polymorphism]. Ai zheng = Aizheng $=$ Chinese journal of cancer 2009;28:1291-1297.

139 Wang ZH, Miao XP, Tan W, Zhang XR, Xu BH, Lin DX. [single nucleotide polymorphisms in xrcc1 and clinical response to platin-based chemotherapy in advanced non-small cell lung cancer $]$. Ai zheng $=$ Aizheng $=$ Chinese journal of cancer 2004;23:865-868.

140 Xu C, Wang X, Zhang Y, Li L. [effect of the xrcc1 and xrcc3 genetic polymorphisms on the efficacy of platinum-based chemotherapy in patients with advanced non-small cell lung cancer]. Zhongguo fei ai za zhi = Chinese journal of lung cancer 2011;14:912-917.

141 Yuan $\mathrm{P}$, Miao XP, Zhang XM, Wang ZH, Tan W, Sun Y, Zhang XR, Xu BH, Lin DX. [xrcc1 and xpd genetic polymorphisms predict clinical responses to platinum-based chemotherapy in advanced non-small cell lung cancer]. Zhonghua zhong liu za zhi [Chinese journal of oncology] 2006;28:196-199.

142 Lee SY, Kang HG, Yoo SS, Kang YR, Choi YY, Lee WK, Choi JE, Jeon HS, Shin KM, Oh IJ, Kim KS, Lee J, Cha SI, Kim CH, Kim YC, Park JY. Polymorphisms in DNA repair and apoptosisrelated genes and clinical outcomes of patients with non-small cell lung cancer treated with first-line paclitaxel-cisplatin chemotherapy. Lung cancer 2013;82:330-339.

143 Zhao W, Hu L, Xu J, Shen H, Hu Z, Ma H, Shu Y, Shao Y, Yin Y. Polymorphisms in the base excision repair pathway modulate prognosis of platinum-based chemotherapy in advanced non-small cell lung cancer. Cancer chemotherapy and pharmacology 2013;71:12871295.

144 Peng Y, Li Z, Zhang S, Xiong Y, Cun Y, Qian C, Li M, Ren T, Xia L, Cheng Y, Wang D. Association of DNA base excision repair genes (ogg1, ape1 and xrcc1) polymorphisms with outcome to platinum-based chemotherapy in advanced nonsmall-cell lung cancer patients. International journal of cancer Journal international du cancer 2014;135:2687-2696.

145 Ke HG, Li J, Shen Y, You QS, Yan Y, Dong HX, Liu JH, Shen ZY. Prognostic significance of gstp1, xrcc1 and $\operatorname{xrcc} 3$ polymorphisms in non-small cell lung cancer patients. Asian Pacific journal of cancer prevention : APJCP 2012;13:4413-4416.

146 Liu JY, Liu QM, Li LR. Association of gstp1 and xrcc1 gene polymorphisms with clinical outcomes of patients with advanced non-small cell lung cancer. Genetics and molecular research : GMR 2015;14:10331-10337.

147 Shrivastav M, De Haro LP, Nickoloff JA. Regulation of DNA double-strand break repair pathway choice. Cell research 2008;18:134-147.

148 Brenneman MA, Wagener BM, Miller CA, Allen C, Nickoloff JA. Xrcc3 controls the fidelity of homologous recombination: Roles for xrcc3 in late stages of recombination. Molecular cell 2002;10:387-395. 
149 Butkiewicz D, Drosik A, Suwinski R, Krzesniak M, Rusin M, Kosarewicz A, Rachtan J, Matuszczyk I, Gawkowska-Suwinska M. Influence of DNA repair gene polymorphisms on prognosis in inoperable non-small cell lung cancer patients treated with radiotherapy and platinum-based chemotherapy. International journal of cancer Journal international du cancer 2012;131:E1100-1108.

150 Chen X, Sun H, Ren S, Kim Curran V, Zhang L, Zhou S, Zhang J, Zhou C. Association of xrcc3 and xpd751 snp with efficacy of platinum-based chemotherapy in advanced nsclc patients. Clinical \& translational oncology : official publication of the Federation of Spanish Oncology Societies and of the National Cancer Institute of Mexico 2012;14:207-213.

151 Yin M, Liao Z, Huang YJ, Liu Z, Yuan X, Gomez D, Wang LE, Wei Q. Polymorphisms of homologous recombination genes and clinical outcomes of non-small cell lung cancer patients treated with definitive radiotherapy. PloS one 2011;6:e20055.

152 Jin ZY, Zhao XT, Zhang LN, Wang Y, Yue WT, Xu SF. Effects of polymorphisms in the xrcc1, xrcc3, and xpg genes on clinical outcomes of platinum-based chemotherapy for treatment of non-small cell lung cancer. Genetics and molecular research : GMR 2014;13:76177625.

153 Fitch ME, Cross IV, Ford JM. P53 responsive nucleotide excision repair gene products p48 and xpc, but not p53, localize to sites of uv-irradiation-induced DNA damage, in vivo. Carcinogenesis 2003;24:843-850.

154 Seo YR, Fishel ML, Amundson S, Kelley MR, Smith ML. Implication of p53 in base excision DNA repair: In vivo evidence. Oncogene 2002;21:731-737.

155 Amaral JD, Xavier JM, Steer CJ, Rodrigues CM. The role of p53 in apoptosis. Discovery medicine 2010;9:145-152.

156 Vousden KH, Lane DP. P53 in health and disease. Nature reviews Molecular cell biology 2007;8:275-283.

157 Weston A, Perrin LS, Forrester K, Hoover RN, Trump BF, Harris CC, Caporaso NE. Allelic frequency of a p53 polymorphism in human lung cancer. Cancer epidemiology, biomarkers \& prevention : a publication of the American Association for Cancer Research, cosponsored by the American Society of Preventive Oncology 1992;1:481-483.

158 Dumont P, Leu Jl, Della Pietra AC, 3rd, George DL, Murphy M. The codon 72 polymorphic variants of p53 have markedly different apoptotic potential. Nature genetics 2003;33:357-365.

159 Bergamaschi D, Gasco M, Hiller L, Sullivan A, Syed N, Trigiante G, Yulug I, Merlano M, Numico G, Comino A, Attard M, Reelfs O, Gusterson B, Bell AK, Heath V, Tavassoli M, Farrell PJ, Smith $\mathrm{P}, \mathrm{Lu} \mathrm{X}$, Crook T. P53 polymorphism influences response in cancer chemotherapy via modulation of p73-dependent apoptosis. Cancer cell 2003;3:387-402.

160 Vikhanskaya F, Siddique MM, Kei Lee M, Broggini M, Sabapathy K. Evaluation of the combined effect of p53 codon 72 polymorphism and hotspot mutations in response to anticancer drugs. Clinical cancer research : an official journal of the American Association for Cancer Research 2005;11:4348-4356.

161 Perez-Ramirez C, Canadas-Garre M, Molina MA, Faus-Dader MJ, Calleja-Hernandez MA. Pten and pi3k/akt in non-small-cell lung cancer. Pharmacogenomics 2015;16:1843-1862.

162 Stoyanov B, Volinia S, Hanck T, Rubio I, Loubtchenkov M, Malek D, Stoyanova S, Vanhaesebroeck B, Dhand R, Nurnberg B, et al. Cloning and characterization of a g proteinactivated human phosphoinositide-3 kinase. Science (New York, NY) 1995;269:690-693. 
163 Rameh LE, Cantley LC. The role of phosphoinositide 3-kinase lipid products in cell function. The Journal of biological chemistry 1999;274:8347-8350.

164 Sansal I, Sellers WR. The biology and clinical relevance of the pten tumor suppressor pathway. Journal of clinical oncology : official journal of the American Society of Clinical Oncology 2004;22:2954-2963.

165 Cantley LC. The phosphoinositide 3-kinase pathway. Science (New York, NY) 2002;296:1655-1657.

166 Duronio $V$. The life of a cell: Apoptosis regulation by the pi3k/pkb pathway. The Biochemical journal 2008;415:333-344.

167 Engelman JA, Luo J, Cantley LC. The evolution of phosphatidylinositol 3-kinases as regulators of growth and metabolism. Nature reviews Genetics 2006;7:606-619.

168 Kim MJ, Kang HG, Lee SY, Jeon HS, Lee WK, Park JY, Lee EB, Lee JH, Cha SI, Kim DS, Kim $\mathrm{CH}$, Kam S, Jung TH, Park JY. Akt1 polymorphisms and survival of early stage non-small cell lung cancer. Journal of surgical oncology 2012;105:167-174.

169 Hoffmeyer S, Burk O, von Richter O, Arnold HP, Brockmoller J, Johne A, Cascorbi I, Gerloff T, Roots I, Eichelbaum M, Brinkmann U. Functional polymorphisms of the human multidrug-resistance gene: Multiple sequence variations and correlation of one allele with $\mathrm{p}$ glycoprotein expression and activity in vivo. Proceedings of the National Academy of Sciences of the United States of America 2000;97:3473-3478.

170 Pan JH, Han JX, Wu JM, Huang HN, Yu QZ, Sheng LJ. Mdr1 single nucleotide polymorphism g2677t/a and haplotype are correlated with response to docetaxel-cisplatin chemotherapy in patients with non-small-cell lung cancer. Respiration; international review of thoracic diseases 2009; 78:49-55.

171 Pan JH, Han JX, Wu JM, Sheng LJ, Huang HN, Yu QZ. Mdr1 single nucleotide polymorphisms predict response to vinorelbine-based chemotherapy in patients with nonsmall cell lung cancer. Respiration; international review of thoracic diseases 2008;75:380-385.

172 Yan PW, Huang XE, Yan F, Xu L, Jiang Y. Influence of mdr1 gene codon 3435 polymorphisms on outcome of platinum-based chemotherapy for advanced non small cell lung cancer. Asian Pacific journal of cancer prevention : APJCP 2011;12:2291-2294.

173 Peklak-Scott C, Smitherman PK, Townsend AJ, Morrow CS. Role of glutathione stransferase $\mathrm{p} 1-1$ in the cellular detoxification of cisplatin. Molecular cancer therapeutics 2008;7:3247-3255.

174 Ekhart C, Rodenhuis S, Smits PH, Beijnen JH, Huitema AD. An overview of the relations between polymorphisms in drug metabolising enzymes and drug transporters and survival after cancer drug treatment. Cancer treatment reviews 2009;35:18-31.

175 Ou C, Zhu B, Zhao HL, Huang LS, Li PZ, Lao M, Li LQ. Association of glutathione stransferase $\mathrm{p} 1$ gene polymorphism with the risk of small-cell carcinoma of lung cancer. Journal of receptor and signal transduction research 2015;35:165-169.

176 Singh S. Cytoprotective and regulatory functions of glutathione s-transferases in cancer cell proliferation and cell death. Cancer chemotherapy and pharmacology 2015;75:1-15.

177 Watson MA, Stewart RK, Smith GB, Massey TE, Bell DA. Human glutathione stransferase $\mathrm{p} 1$ polymorphisms: Relationship to lung tissue enzyme activity and population frequency distribution. Carcinogenesis 1998;19:275-280.

178 Yang P, Mandrekar SJ, Hillman SH, Allen Ziegler KL, Sun Z, Wampfler JA, Cunningham JM, Sloan JA, Adjei AA, Perez E, Jett JR. Evaluation of glutathione metabolic genes on outcomes 
in advanced non-small cell lung cancer patients after initial treatment with platinum-based chemotherapy: An ncctg-97-24-51 based study. J Thorac Oncol 2009;4:479-485.

179 Bailey LB, Gregory JF, 3rd. Folate metabolism and requirements. The Journal of nutrition 1999;129:779-782.

180 Wang L, Shangguan S, Chang S, Yu X, Wang Z, Lu X, Wu L, Zhang T. Determining the association between methylenetetrahydrofolate reductase (mthfr) gene polymorphisms and genomic DNA methylation level: A meta-analysis. Birth defects research Part A, Clinical and molecular teratology 2016

181 Hanks J, Ayed I, Kukreja N, Rogers C, Harris J, Gheorghiu A, Liu CL, Emery P, Pufulete M. The association between mthfr 677c>t genotype and folate status and genomic and genespecific DNA methylation in the colon of individuals without colorectal neoplasia. The American journal of clinical nutrition 2013;98:1564-1574.

182 Yamada K, Chen Z, Rozen R, Matthews RG. Effects of common polymorphisms on the properties of recombinant human methylenetetrahydrofolate reductase. Proceedings of the National Academy of Sciences of the United States of America 2001;98:14853-14858.

183 Izmirli M. A literature review of mthfr (c677t and a1298c polymorphisms) and cancer risk. Molecular biology reports 2013;40:625-637.

184 Song MA, Brasky TM, Marian C, Weng DY, Taslim C, Llanos AA, Dumitrescu RG, Liu Z, Mason JB, Spear SL, Kallakury BV, Freudenheim JL, Shields PG. Genetic variation in one-carbon metabolism in relation to genome-wide DNA methylation in breast tissue from heathy women. Carcinogenesis 2016

185 Li X, Shao M, Wang S, Zhao X, Chen H, Qian J, Song X, Wang J, Jin L, Wu J, Li Q, Bai C, Han B, Gao Z, Lu D. Heterozygote advantage of methylenetetrahydrofolate reductase polymorphisms on clinical outcomes in advanced non-small cell lung cancer (nsclc) patients treated with platinum-based chemotherapy. Tumour biology : the journal of the International Society for Oncodevelopmental Biology and Medicine 2014;35:11159-11170.

186 Leclerc D, Campeau E, Goyette P, Adjalla CE, Christensen B, Ross M, Eydoux P, Rosenblatt DS, Rozen R, Gravel RA. Human methionine synthase: Cdna cloning and identification of mutations in patients of the cblg complementation group of folate/cobalamin disorders. Human molecular genetics 1996;5:1867-1874.

187 Sharp L, Little J. Polymorphisms in genes involved in folate metabolism and colorectal neoplasia: A huge review. American journal of epidemiology 2004;159:423-443.

188 Azzoli CG, Baker S, Temin S, Pao W, Aliff T, Brahmer J, Johnson DH, Laskin JL, Masters $G$, Milton D. American society of clinical oncology clinical practice guideline update on chemotherapy for stage iv non-small-cell lung cancer. J Clin Oncol 2009;27:6251-6266.

189 Adjei AA, Salavaggione OE, Mandrekar SJ, Dy GK, Ziegler KL, Endo C, Molina JR, Schild $\mathrm{SE}$, Adjei AA. Correlation between polymorphisms of the reduced folate carrier gene (slc19a1) and survival after pemetrexed-based therapy in non-small cell lung cancer: A north central cancer treatment group-based exploratory study. J Thorac Oncol 2010;5:1346-1353.

190 Li WJ, Jiang H, Fang XJ, Ye HL, Liu MH, Liu YW, Chen Q, Zhang L, Zhang JY, Yuan CL, Zhang QY. Polymorphisms in thymidylate synthase and reduced folate carrier () genes predict survival outcome in advanced non-small cell lung cancer patients treated with pemetrexedbased chemotherapy. Oncology letters 2013;5:1165-1170.

191 Smit EF, Burgers SA, Biesma B, Smit HJ, Eppinga $P$, Dingemans AM, Joerger $M$, Schellens JH, Vincent A, van Zandwijk N, Groen HJ. Randomized phase ii and pharmacogenetic study of pemetrexed compared with pemetrexed plus carboplatin in pretreated patients with 
advanced non-small-cell lung cancer. Journal of clinical oncology : official journal of the American Society of Clinical Oncology 2009;27:2038-2045.

192 Coussens LM, Werb Z. Inflammation and cancer. Nature 2002;420:860-867.

193 Lin WW, Karin M. A cytokine-mediated link between innate immunity, inflammation, and cancer. The Journal of clinical investigation 2007;117:1175-1183.

194 Aggarwal BB, Vijayalekshmi RV, Sung B. Targeting inflammatory pathways for prevention and therapy of cancer: Short-term friend, long-term foe. Clinical cancer research : an official journal of the American Association for Cancer Research 2009;15:425-430.

195 Dranoff G. Cytokines in cancer pathogenesis and cancer therapy. Nature reviews Cancer 2004;4:11-22.

Graphical Abstract

Figure 1. DNA repair pathways involved in removal DNA lesions produced by platinum compounds. 